\title{
Nepal Ambient Monitoring and Source Testing Experiment (NAMaSTE): emissions of particulate matter from wood- and dung-fueled cooking fires, garbage and crop residue burning, brick kilns, and other sources
}

\author{
Thilina Jayarathne $^{1}$, Chelsea E. Stockwell ${ }^{2}$, Prakash V. Bhave ${ }^{3}$, Puppala S. Praveen ${ }^{3}$, Chathurika M. Rathnayake ${ }^{1}$, \\ Md. Robiul Islam ${ }^{1}$, Arnico K. Panday ${ }^{3}$, Sagar Adhikari ${ }^{4}$, Rashmi Maharjan ${ }^{4}$, J. Douglas Goetz ${ }^{5}$, Peter F. DeCarlo ${ }^{5,6}$, \\ Eri Saikawa $^{7}$, Robert J. Yokelson ${ }^{2}$, and Elizabeth A. Stone ${ }^{1,8}$ \\ ${ }^{1}$ University of Iowa, Department of Chemistry, Iowa City, IA, USA \\ ${ }^{2}$ University of Montana, Department of Chemistry, Missoula, MT, USA \\ ${ }^{3}$ International Centre for Integrated Mountain Development (ICIMOD), Khumaltar, Lalitpur, Nepal \\ ${ }^{4}$ MinErgy Pvt. Ltd, Lalitpur, Nepal \\ ${ }^{5}$ Drexel University, Department of Civil, Architectural, and Environmental Engineering, Philadelphia, PA, USA \\ ${ }^{6}$ Drexel University, Department of Chemistry, Philadelphia, PA, USA \\ ${ }^{7}$ Emory University, Department of Environmental Sciences, Atlanta, GA, USA \\ ${ }^{8}$ University of Iowa, Department of Chemical and Biochemical Engineering, Iowa City, IA, USA
}

Correspondence: Elizabeth A. Stone (betsy-stone@uiowa.edu)

Received: 31 May 2017 - Discussion started: 9 June 2017

Revised: 16 October 2017 - Accepted: 17 October 2017 - Published: 15 February 2018

\begin{abstract}
The Nepal Ambient Monitoring and Source Testing Experiment (NAMaSTE) characterized widespread and under-sampled combustion sources common to South Asia, including brick kilns, garbage burning, diesel and gasoline generators, diesel groundwater pumps, idling motorcycles, traditional and modern cooking stoves and fires, crop residue burning, and heating fire. Fuel-based emission factors (EFs; with units of pollutant mass emitted per kilogram of fuel combusted) were determined for fine particulate matter $\left(\mathrm{PM}_{2.5}\right)$, organic carbon (OC), elemental carbon (EC), inorganic ions, trace metals, and organic species. For the forced-draft zigzag brick kiln, $\mathrm{EF}_{\mathrm{PM}_{2.5}}$ ranged from 12 to $19 \mathrm{~g} \mathrm{~kg}^{-1}$ with major contributions from OC (7\%), sulfate expected to be in the form of sulfuric acid (31.9\%), and other chemicals not measured (e.g., particle-bound water). For the clamp kiln, $\mathrm{EF}_{\mathrm{PM}_{2.5}}$ ranged from 8 to $13 \mathrm{~g} \mathrm{~kg}^{-1}$, with major contributions from OC (63.2\%), sulfate (23.4\%), and ammonium (16\%). Our brick kiln $\mathrm{EF}_{\mathrm{PM}_{2.5}}$ values may exceed those previously reported, partly because we sampled emissions at ambient temperature after emission from the stack or kiln allowing some particle-phase OC and sulfate
\end{abstract}

to form from gaseous precursors. The combustion of mixed household garbage under dry conditions had an $\mathrm{EF}_{\mathrm{PM}_{2.5}}$ of $7.4 \pm 1.2 \mathrm{~g} \mathrm{~kg}^{-1}$, whereas damp conditions generated the highest $\mathrm{EF}_{\mathrm{PM}_{2.5}}$ of all combustion sources in this study, reaching up to $125 \pm 23 \mathrm{~g} \mathrm{~kg}^{-1}$. Garbage burning emissions contained triphenylbenzene and relatively high concentrations of heavy metals $(\mathrm{Cu}, \mathrm{Pb}, \mathrm{Sb})$, making these useful markers of this source. A variety of cooking stoves and fires fueled with dung, hardwood, twigs, and/or other biofuels were studied. The use of dung for cooking and heating produced higher $\mathrm{EF}_{\mathrm{PM}_{2.5}}$ than other biofuel sources and consistently emitted more $\mathrm{PM}_{2.5}$ and $\mathrm{OC}$ than burning hardwood and/or twigs; this trend was consistent across traditional mud stoves, chimney stoves, and three-stone cooking fires. The comparisons of different cooking stoves and cooking fires revealed the highest PM emissions from threestone cooking fires $\left(7.6-73 \mathrm{~g} \mathrm{~kg}^{-1}\right)$, followed by traditional mud stoves (5.3-19.7 $\left.\mathrm{g} \mathrm{kg}^{-1}\right)$, mud stoves with a chimney for exhaust (3.0-6.8 $\left.\mathrm{g} \mathrm{kg}^{-1}\right)$, rocket stoves $\left(1.5-7.2 \mathrm{~g} \mathrm{~kg}^{-1}\right.$ ), induced-draft stoves $\left(1.2-5.7 \mathrm{~g} \mathrm{~kg}^{-1}\right)$, and the bhuse chulo stove $\left(3.2 \mathrm{~g} \mathrm{~kg}^{-1}\right)$, while biogas had no detectable PM emis- 
sions. Idling motorcycle emissions were evaluated before and after routine servicing at a local shop, which decreased $\mathrm{EF}_{\mathrm{PM}_{2.5}}$ from $8.8 \pm 1.3$ to $0.71 \pm 0.45 \mathrm{~g} \mathrm{~kg}^{-1}$ when averaged across five motorcycles. Organic species analysis indicated that this reduction in $\mathrm{PM}_{2.5}$ was largely due to a decrease in emission of motor oil, probably from the crankcase. The EF and chemical emissions profiles developed in this study may be used for source apportionment and to update regional emission inventories.

\section{Introduction}

Insufficient knowledge of air pollution sources in South Asia hinders the development of pollution mitigation strategies to protect public health (Gurung and Bell, 2013) and model representation of air quality and climate on local to global scales (Adhikary et al., 2007; Bond et al., 2013). Prevalent but under-characterized combustion emission sources in South Asia include traffic, brick kilns, garbage burning, cooking stoves, and the open burning of biomass. To begin to address this gap, the Nepal Ambient Monitoring and Source Testing Experiment (NAMaSTE) was conducted to (i) characterize the emissions of gas and particle species produced by the many important combustion sources in Nepal as a model for South Asia, (ii) develop emission factors and detailed emissions profiles for these sources to support revisions to regional emissions inventories, and (iii) apply knowledge of source emissions to improve source apportionment of ambient air pollution. During April 2015, a moveable laboratory was deployed in Nepal to characterize in situ emissions from brick kilns, garbage burning, diesel and gasoline generators, diesel groundwater pumps, motorcycles, traditional and modern cooking stoves, and agricultural residue burning. Additional source emission tests were planned but canceled in response to the Ghorka earthquake that struck on 25 April. Emissions of major gases (carbon dioxide $\left(\mathrm{CO}_{2}\right)$, carbon monoxide $(\mathrm{CO})$, methane $\left(\mathrm{CH}_{4}\right)$, ammonia $\left(\mathrm{NH}_{3}\right)$, hydrochloric acid $(\mathrm{HCl})$ ), non-methane organic gases, and light-absorbing carbon ("brown carbon" (BrC) and black carbon $(\mathrm{BC})$ ) for these sources are reported by Stockwell et al. (2016). Further characterization of size-resolved particulate matter (PM) emissions by aerosol mass spectrometry (AMS) is underway (Goetz et al., 2018a, b). In this paper, PM emission factors and chemical composition for these combustion sources are reported.

Across the Indo-Gangetic plains (IGPs), brick kilns generate a substantial amount of building materials. Bricks are dried and kilns are fired during the dry winter season, generally spanning from October to March in the IGPs. The Kathmandu Valley in Nepal contains more than 110 brick kilns (Federation of Nepal Brick Industries, 2016) and the greater Dhaka region contains 1000 kilns (Guttikunda et al., 2013). Kilns vary in design, with some producing bricks in batches and others continuously; some have chimneys and others ventilate through gaps; some are forced-draft and others are natural-draft. Descriptions of common kiln types are provided elsewhere (Weyant et al., 2014; UNEP, 2014). In NAMaSTE, emissions from two types of brick kilns were examined: zigzag and clamp kilns. The zigzag kiln is a continuous, moving fire kiln that is capable of producing 1-10 million bricks during a firing season. Air moves in a zigzag pattern through stacks of bricks and is vented through a central smoke stack. The forced-draft style employs a fan to generate air flow. The zigzag configuration provides more even heating of bricks and yields a higher-quality product (UNEP, 2014) while consuming less energy per brick fired than the straight-line configuration used in the most common fixedchimney Bull trench kilns around South Asia. The clamp kiln is a smaller batch-style kiln that produces 10000-200000 bricks per batch (and less than 1 million bricks per season) (UNEP, 2014). Unfired ("green") bricks are stacked in the center with fired bricks surrounding these; fuel - typically coal and biomass - is interspersed with the green bricks and ignited. There is no chimney and smoke escapes from the cracks in the top of the kiln. Some clamp kilns have been phased out in more industrialized areas in favor of continuous kilns that afford better efficiency, but this kiln type remains common in rural areas. Brick kilns are often fueled by low-quality coal, which is often supplemented with biomass (sawdust, briquettes, bagasse, etc.) or scrap tires (Maithel et al., 2012). Plumes of smoke are visible when kilns are in operation. Studies of several types of South Asian brick kilns have revealed that the bulk chemical composition of the PM is dominated by organic and elemental carbon (Weyant et al., 2014). Moreover, studies in Mexico reveal that the PM also contains chloride and trace metals (Christian et al., 2010). Occupational exposure to brick kiln emissions can cause significantly reduced lung function (Zuskin et al., 1998) and oxidative stress (Kaushik et al., 2012). Because of the prevalence of brick kilns in South Asia, and their potential for significant local and regional influence on air quality, it is important to evaluate the amount and chemical composition of particulate matter emitted, to further support source attribution, emissions inventories, and air quality modeling.

Globally, 2400 billion tons of domestic solid waste are estimated to be generated yearly, of which an estimated $41 \%$ is disposed through open burning, making garbage burning a significant source of air pollution (Wiedinmyer et al., 2014). In countries that lack programs for waste collection and disposal and/or with a large rural population, the extent of garbage burning is greater. For example, in Nepal, it was estimated that 1.1 million tons of waste were generated in 2013 , the majority of which were not collected $(>84 \%)$ and were ultimately burned at residential or dump sites $(60 \%)$ (Wiedinmyer et al., 2014). In Kathmandu, much of the open waste burning occurs either in large trash piles accumulated on river banks or in small piles on streets and sidewalks. Although recognized as an important source of air pollution, 
the regional and global air quality impact of garbage burning remains highly uncertain due to limited data on the amount of waste burned and the quantity of pollutants emitted for different types of waste and burn conditions (Wiedinmyer et al., 2014). The challenges in characterizing emissions from the open-burning of garbage include the fuel's inherent heterogeneity, various and often low-technology practices for burning garbage, and the range of scales on which it occurs, from residential point sources to municipal-scale dump sites (Bond et al., 2004). PM emitted from garbage burning contains significant amounts of organic and elemental carbon, with additional contributions from polycyclic aromatic hydrocarbons (PAHs), polychlorinated dioxins and furans, and trace metals (e.g., $\mathrm{Sb}, \mathrm{Cu}, \mathrm{Zn}, \mathrm{Zb}, \mathrm{Pb}, \mathrm{V}$, As) (Woodall et al., 2012; Christian et al., 2010; Simoneit et al., 2005). Given the hazardous nature of garbage burning emissions and the widespread practice of burning garbage, it is important to evaluate the emissions from this source under real-world open-burning conditions.

Generators, powered by gasoline or diesel, are used in South Asia for electrical power generation, particularly in the absence of electricity provided by utilities through gridbased networks. In the Kathmandu Valley, generators are widely used for backup power during power outages that were frequent and widespread until November 2016. Load shedding cut power to households upwards of $40 \mathrm{~h}$ per week in Kathmandu, particularly during the dry winter season when water levels in rivers that provide hydroelectric power were low. Generator PM emissions vary greatly with generator model and manufacturer, fuel, engine size, engine load, running time, unit age, and maintenance (Zhu et al., 2009; Lin et al., 2006; Shah et al., 2006a). PM emissions from diesel engines are primarily elemental carbon and organic matter that result from combustion and/or the evaporation of fuel or engine oil (Liang et al., 2005; Schauer et al., 1999, 2002). Although sharing many similarities, emissions from generators that operate under near-steady-state to steadystate conditions vary from those of on-road vehicle engines that operate under transient conditions (Shah et al., 2006a). Within this study, emissions from gasoline and diesel generators were characterized to gain further insight into this widely used combustion source.

Groundwater pumps are widely used in South Asia as a means of accessing a consistent source of irrigation water, strengthening agrarian communities, and improving food security among growing populations, particularly in arid regions. Groundwater pump use has greatly expanded since emerging in the 1970s, with nearly 20 million pumps in use in India, Bangladesh, Pakistan, and the plains in southern Nepal known as the Tarai in 2000 (Shah, 2009), although the number and location of such pumps are not well documented (Rawat and Mukherji, 2014). Pumps may be powered by either electricity or diesel, with the choice largely determined by energy prices and supply (Shah et al., 2006b). Diesel is the predominant fuel used $(>84 \%)$ in the IGPs, including the Nepal Tarai (Shah, 2009; Shah et al., 2006b), while electricity and diesel have comparable market shares in India (Mukherji, 2008). Diesel PM is recognized by the International Agency for Research on Cancer as a group 1 carcinogen (IARC, 2013) and includes black carbon, a shortlived climate forcing agent (Ramanathan et al., 2005). In this study, we characterized the magnitude and chemical composition of PM emissions from two diesel groundwater pumps used in the Tarai region of Nepal.

Motorcycles are widely used for transportation in urban areas of Asia. In Nepal, they account for $80 \%$ of the vehicle fleet, consume $9 \%$ of the transport sector's fuel, and are undergoing the fastest growth of any vehicle sector (WECS, 2014; Ministry of Physical Infrastructure \& Transport, MoPIT, 2014). The motorcycles tested during NAMaSTE were 3-15 years old at the time of sampling and had four-stroke engines (Stockwell et al., 2016), which is the most common engine type in Nepal (Shrestha et al., 2013). The motorcycles were manufactured in India and because four-stroke engines were not required to have catalytic converters until 2015 in India, it was assumed that the motorcycles tested did not have them (Stockwell et al., 2016). The absence of a catalytic converter leads to higher PM and PAH emissions, as do cold starts when the catalyst is not fully operational (Spezzano et al., 2008). Emissions from vehicles in Kathmandu tend to be higher than in other parts of the world, due to steep gradients, congested traffic, low vehicle speeds, high altitude, and frequent restarting (Shrestha et al., 2013); these conditions, despite their low engine stress, are responsible for high emissions of $\mathrm{CO}$, volatile organic compounds (VOCs), and PM (Oanh et al., 2012). In this study, the combined emissions from five motorcycles under idling conditions were evaluated before and after basic servicing. Although limited in scope, this study design provides insight into emissions reductions that may be achieved by servicing.

Biofuels are widely used in Asia as a source of energy for cooking and heating (Yevich and Logan, 2003). In the IGPs, dung cake (formed by mixing cow dung and straw), fuelwood, and crop residue are major sources of household energy (Saud et al., 2011). Agricultural residues are also often burned in the fields at the end of the season to clear fields and return nutrients to the soil, and this constitutes a major emission source (Yevich and Logan, 2003). Traditionally, cooking has involved the use of biofuels either in an open fire built between stones that support a pot (a.k.a. three-stone fire) or in a closed fire in a mud structure (traditional mud stoves), which are located indoors and often do not have a chimney. Cooking indoors with high-emitting stoves produces a large fraction of regional emissions (Ramanathan and Carmichael, 2008) and the poor ventilation leads to high exposures to $\mathrm{CO}$, other toxic gases, and PM, particularly for women and children who spend more time indoors near the combustion source (Davidson et al., 1986; Smith et al., 2013). Exposures are associated with myriad negative health outcomes including respiratory infections and low birth weight (Pope et al., 2010) 
that lead to premature mortality (Fullerton et al., 2008). To mitigate this risk, recent research efforts have focused on developing more efficient and less polluting cooking technologies (Kshirsagar and Kalamkar, 2014). Within this study, PM emissions from traditional and modern cooking technologies were evaluated using a variety of biofuels, with the goals of developing detailed chemical profiles of cooking stove emissions and assessing differences in emissions across fuel and stove types. In addition, in situ emissions from springtime agricultural residue burning in the field in the Tarai and from heating fires were also characterized.

The NAMaSTE campaign took place in two regions of Nepal: in and around Kathmandu and in the Tarai; this provided access to numerous combustion sources of regional interest. Kathmandu, the capital of Nepal, suffers from high levels of fine particulate matter $\left(\mathrm{PM}_{2.5}\right)$ and gas-phase pollutants (Aryal et al., 2009). High pollution levels in Kathmandu are a consequence of its growing population, rapidly expanding vehicular fleet (Shrestha et al., 2013), unpaved roadways, insufficient electrical power, widespread use of solid fuels for household energy needs (Smith et al., 2013), and the common practice of burning garbage (Wiedinmyer et al., 2014). Further, its valley topography that traps pollutants and its long dry season are responsible for a daily pollution buildup (Panday et al., 2009). Kathmandu and its surroundings provided access to many targeted source types, including brick kilns, garbage burning, cooking stoves, motorcycles, and diesel generators. The Tarai, a predominantly agricultural region of southern Nepal, provided access to diesel groundwater pumps, agricultural residue burning, garbage burning, and additional samples of household biofuel combustion.

Emission factors (EFs) for combustion sources were determined by the carbon mass balance approach (Ward and Radke, 1993; Yokelson et al., 1999; Yokelson et al., 1996). Chemical profiles of $\mathrm{PM}_{2.5}$ were developed by quantifying PM mass, organic and elemental carbon (OC and EC), watersoluble/insoluble organic carbon (WSOC/WIOC), watersoluble inorganic ions, metals, and organic species. Reported herein are the first detailed chemical profiles for many sources in South Asia, including clamp kilns, garbage burning, and diesel groundwater pumps. These particulate phase measurements, in combination with gas-phase, optical, and additional PM measurements reported in our companion papers by Stockwell et al. (2016) and Goetz et al. (2017a), provide a detailed chemical description of these source emissions. These new emissions data can be used when expanding and updating emissions inventories, as source profiles in receptor-based source apportionment modeling, or to model exposures to air pollutants. More broadly, these data can provide a more accurate representation of the sources of air pollutants in Nepal and the rest of South Asia and thus support evaluating air pollution impacts on climate and health as well as guiding mitigation strategies. NAMaSTE provides new insights into South Asian combustion emissions, but further re- search is needed to achieve a full understanding of the diversity, variability, and abundance of these emissions sources on a regional scale.

\section{Methods}

\subsection{Field study of combustion emissions}

NAMaSTE took place in and around Kathmandu Valley and in the Tarai region of southern Nepal from 11 to 25 April 2015. Because of the magnitude 7.9 Gorkha earthquake in Nepal on 25 April 2015, the study ended earlier than planned, before additional sources could be sampled.

\subsubsection{Sample collection}

$\mathrm{PM}_{2.5}$ was collected using a custom-built, dual-channel PM sampler. Smoke was drawn through two side-by-side sample inlets that were mounted on a $\sim 2.5 \mathrm{~m}$ long pole, to allow post-emission sampling of the smoke from a safe distance, typically $2-3 \mathrm{~m}$ downwind of the stack or combustion source. The pole upon which the inlets were mounted was positioned manually to sample the plume where the plume of smoke was well-mixed and had cooled to near-ambient temperatures. During the period of sample collection, ambient temperatures ranged from 12 to $29^{\circ} \mathrm{C}$ (on a 5 min basis) in the Kathmandu Valley and averaged $19^{\circ} \mathrm{C}$. Air was drawn through copper tubing to $2.5 \mu \mathrm{m}$ sharp-cut cyclones (URG Corp.) followed by two Teflon-coated filter holders (ColeParmer). PM was collected on both $47 \mathrm{~mm}$ quartz fiber filters (QFFs; Whatman) and $47 \mathrm{~mm}$ Teflon filters (PALL, Life Sciences). Air flow was maintained at a constant flow rate of $7.5 \mathrm{~L} \mathrm{~min}^{-1}$ through each channel and was logged continuously by flowmeters (APEX, Inc.). The sampled air volume was calculated as the product of the average air flow rate through the filter and total sampling time. The filtered air was then passed to the land-based Fourier transform infrared (LA-FTIR) spectrometer multi-pass cell for the measurement of gas-phase species as described by Stockwell et al. (2016).

Prior to sample collection, QFFs were prebaked at $550{ }^{\circ} \mathrm{C}$ for $18 \mathrm{~h}$ to remove contaminants and stored in aluminumfoil-lined petri dishes. For some samples, a second (backup) QFF was placed in series behind the first (front) QFF in order to assess gas adsorption to the front filter. Teflon filters were pre-weighed as described in Sect. 2.2.1 and stored in plastic petri dishes. All petri dishes were sealed with Teflon tape before and after sampling. Field blanks were collected for every fifth sample. Filters were stored in a freezer at $-20^{\circ} \mathrm{C}$ before and after sample collection and were shipped frozen to the University of Iowa for chemical analysis. Reported values are corrected for positive sampling artifacts and were field blank subtracted. 


\subsubsection{Combustion sources}

The combustion sources analyzed are summarized in Table S1 (with the utilized fuels, location and duration of sampling, and average PM mass concentrations). The sources studied in NAMaSTE represent a small sample of a diverse population of combustion sources in Nepal and South Asia. The experiment was designed to characterize previously uncharacterized or under-sampled sources recognized as important to the region, with a high degree of chemical detail. The relatively small number of samples collected within each source category limits our understanding of the emissions variability within a source category and the representativeness of the studied samples of the broader population. Descriptions of each source are provided below, with reference to our companion paper (Stockwell et al., 2016) for additional information when available.

Emissions from seven cooking technologies were examined at the Renewable Energy Testing Station (RETS) in Kathmandu. Laboratory tests were used to study emissions from various stoves as they brought a pot of water to boil from a cold start (i.e., room temperature) to simulate cooking. These tests did not strictly follow a controlled protocol (e.g., the Water Boiling Test), such that stove efficiency was not determined. The studied stoves included traditional mud stoves, a chimney stove, a natural-draft rocket stove, an induced-draft stove, a bhuse chulo (insulated vertical combustion chamber), a forced-draft biobriquette stove with an electrical charger, and a biogas burner. Emissions from threestone fires were also examined but not under cooking conditions (i.e., no water was boiled); consequently, this source is referred to as a "cooking fire" rather than a "cooking stove". The fires at RETS were fueled with hardwood, dung, twigs, mixtures thereof, sawdust, biobriquettes, or biogas (Table S1). Our data analysis emphasizes differences across fuels and technologies. A summary of the types of cooking stoves and fires studied at RETS is provided in Table S2 with a brief description of their typical operation and photograph for most stove types. The in situ testing of cooking fires in the Tarai homes and a restaurant operated out of a personal kitchen provided real-world emissions samples from traditional mud stoves of the one- or two-pot design that were fired with hardwood, twigs, dung, or a mixture of dung and hardwood while normal cooking operations occurred. In sampling emissions from cooking fires, the inlets were positioned in a corner of the home to sample well-mixed integrated emissions.

Samples from all other sources were collected in the field. Agricultural waste burning was sampled in the Tarai and the filter samples were of co-burned rice, wheat, mustard, lentil, and grass residues. A heating fire was sampled in the Tarai, in which dung and twigs were openly burned to generate heat.

Brick kilns were studied near the Kathmandu Valley. For the zigzag kiln, emissions were examined over the course of $5 \mathrm{~h}$, which captured several fuel feeding cycles in which coal and bagasse were added to the kiln. Three filter samples were collected from smoke escaping from the chimney, with each filter sampled only when the plume reached the sampling inlet. Emissions from the clamp kiln were also collected in triplicate. The clamp kiln was fueled primarily with coal and was co-fired with hardwood, although most of the hardwood was likely consumed before we sampled this kiln late in its 18day firing cycle. Chemical analysis of the coal burned and bricks produced by each kiln are provided by Stockwell et al. (2016, see Table S3).

Emissions from petrol (4 kVA, 3 years old) and diesel ( $5 \mathrm{kVA}, 4$ years old) generators were evaluated, using equipment rented in Kathmandu. Both generators had four-stroke engines and were of a size that is commonly used on household or small to medium commercial scales. Generators were run without any electrical load (i.e., idling) and we estimate that they were running at approximately $20 \%$ capacity based on other idling generator tests performed in a followup study. Filter sampling occurred when the generator was under continuous operating conditions (i.e., not during startup). Diesel sold by the Nepal Oil Corporation specifies that sulfur content is less than $350 \mathrm{mg} \mathrm{kg}^{-1}$, while the diesel sold in 2015 (for which data are available) ranged from 165 to $337 \mathrm{mg} \mathrm{kg}^{-1}$ and averaged $240 \mathrm{mg} \mathrm{kg}^{-1}$.

In the Tarai region, emissions from two diesel groundwater pumps were studied. Pump 1 (4.6 kVA) was approximately 3 years old, while pump $2(5 \mathrm{kVA})$ had been in use for less than 3 months. The pumps failed shortly after startup on several occasions and were subsequently restarted. Filter samples were collected after the groundwater pumps had reached continuous operating conditions, which occurred approximately $8 \mathrm{~min}$ after a successful start-up. Consequently, the filter samples do not include the initial start-up phase, which was captured by real-time gas-phase emissions monitoring (Stockwell et al., 2016), during which the pumps were visually observed to emit puffs of black smoke.

Emissions from five motorcycles while idling were evaluated before and after servicing, which involved an oil change, cleaning air filters and spark plugs, and adjusting the carburetor. Filter samples were collected as a composite of emissions from five vehicles, each sampled one by one, for approximately $10 \mathrm{~min}$ each, onto the same filter. The motorcycles had four-stroke engines, were powered by gasoline, and were one of four models (Honda Hero CBZ, Honda Hero Splendor, Honda Aviator, Bajaj Pulsar) that ranged in age from 3 to 15 years; details of their mileage at last service, total vehicle mileage, and age since purchase are provided by Stockwell et al. (2016, see Table S1). The studied motorcycles are among the most common models in Kathmandu (Shrestha et al., 2013).

Emissions from garbage burning were studied for mixed garbage $(n=3)$ and sorted trash that isolated foil-lined bags $(n=1)$ and mostly plastic burning $(n=1)$. Fires were ignited shortly before sample collection. Two distinct conditions were studied: damp conditions in Kathmandu and dry 
conditions in the Tarai. Garbage burning under dry conditions is assumed to prevail and is used in the best estimate of $\mathrm{EF}_{\mathrm{PM}_{2.5}}$ as discussed in Sect. 3.3. The garbage burning emissions sampled in the Tarai were collected from a mixture of typical domestic waste that included cardboard and chip bags. Four additional samples of PM from garbage burning were collected in Kathmandu in which the material was damp from rainfall the previous night and the fire was rekindled with newspaper on occasion (Stockwell et al., 2016); these samples are more representative of conditions where inorganic waste and damp organic waste are burned together at a dump site. The mixed-garbage sample in Kathmandu included food waste, paper, plastic bags, cloth, diapers, and rubber shoes and was sampled twice, whereas other garbage burning emissions were sampled only once. Some garbage was sorted to gain insight into emissions from specific garbage components. One such sample of plastic mostly consisted of heavy clear plastic, some plastic cups, and food bags that were predominantly made of polyethylene. Another such sample of foil wrappers included chip bags, candy wrappers, and aluminum-foil-lined bags. Details of the garbage composition and sampling details are provided by Stockwell et al. (2016, see Table S2).

\subsection{Chemical analysis of particulate matter}

\subsubsection{Measurement of $\mathbf{P M}_{2.5}$ mass}

Before and after sample collection, Teflon filters were conditioned for $48 \mathrm{~h}$ in a desiccator and weighed using an analytical microbalance (Mettler Toledo XP26) in a temperature$\left(22.0 \pm 0.5^{\circ} \mathrm{C}\right)$ and humidity- $(34 \pm 12 \%)$ controlled room. PM mass was calculated as the difference of pre- and postsampling filter weights, each determined in triplicate. PM masses were converted to mass concentrations $\left(\mu \mathrm{g} \mathrm{m}^{-3}\right)$ by dividing by the sampled air volume. There was no detectable increase in field blank filter masses, and thus no field blank subtraction was applied. The relative error in the PM mass measurements was propagated from the standard deviation of field blank filter masses (an estimate of method precision) and $15 \%$ of the measured value (to account for potential background influences, described in Sect. 3).

\subsubsection{Elemental and organic carbon}

Organic carbon and elemental carbon were determined following the NIOSH 5040 method (NIOSH, 2003) on $1.0 \mathrm{~cm}^{2}$ punches of QFF (Sunset OC-EC Aerosol Analyzer, Sunset Laboratories, Tigard, OR). All OC measurements were field blank subtracted and adjusted for positive sampling artifacts. The fraction of OC on quartz fiber backup filters relative to the front quartz fiber filters was used to estimate positive sampling artifacts from gas adsorption and was subtracted from the front filters (Kirchstetter et al., 2001). Potential biases in this approach derive from differential sorption on the front filter compared to the back filter, leading to additional uncharacterized measurement uncertainties. EC was not detected on any backup filters, indicating that PM collection of the front filter was sufficiently high for breakthrough to be negligible. A field blank subtraction was applied for OC and the amount of OC on field blanks was $<18 \%$ of the OC on sampled filters. EC was not detected on field blanks such that no EC field blank subtraction was applied. Uncertainty in OC measurements was propagated from the standard deviation of the field blank OC levels and $10 \%$ of the OC concentration, a conservative estimate of the precision error in replicate sample analysis (NIOSH, 2003). Uncertainty in EC measurements was propagated from the instrumental uncertainty $\left(0.05 \mu \mathrm{g} \mathrm{cm}^{-2}\right), 10 \%$ of the measured EC, and $10 \%$ of pyrolyzed carbon, which refers to OC that charred during analysis.

\subsubsection{Water-soluble organic carbon}

A subsample of QFF (taken with a machined $1.053 \mathrm{~cm}^{2}$ punch) was analyzed for WSOC using a total OC analyzer (GE, Sievers $5310 \mathrm{C}$ ) following a methodology described elsewhere (Budisulistiorini et al., 2015). WSOC was extracted into $15.0 \mathrm{~mL}$ of $>18.2 \mathrm{M} \Omega$ resistivity ultra-pure water (Thermo, Barnstead Easypure II) using acid-washed $\left(10 \%\right.$ nitric acid) and prebaked $\left(550^{\circ} \mathrm{C}\right.$ for $\left.5.5 \mathrm{~h}\right)$ glassware. Inorganic carbon was removed with an inorganic carbon remover (GE, Sievers ICR). WSOC was quantified using standard calibration curves prepared from potassium hydrogen phthalate (Ultra Scientific). The amount of WSOC recovered from field blanks was small in comparison to source samples that contained appreciable amounts of WSOC (e.g., $<20 \%$ for biofuel emissions and mixed-garbage burning) but larger for samples with primarily water-insoluble OC (e.g., approximately $60 \%$ for fossil fuel). Water-soluble and water-insoluble fractions of $\mathrm{OC}$ were calculated relative to the total OC on the front filter and scaled to the artifactcorrected OC assuming equivalent sorption of water-soluble and water-insoluble gases.

\subsubsection{Measurement of inorganic ions by ion chromatography}

Inorganic ions were quantified in aqueous extracts of filter samples by ion exchange chromatography with conductivity detection (Dionex-ICS 5000). Sample preparation, analysis, and instrument detection limits followed Jayarathne et al. (2014). The uncertainty was propagated using the average field blank, the standard deviation of the field blanks, and $10 \%$ of the ion concentration. Results are reported only for ions whose concentrations are greater than the sum of either the mean field blank levels or the method detection limit (Jayarathne et al., 2014), whichever was larger, plus 3 times the standard deviation of the field blank. 


\subsubsection{Quantification of metals by inductively coupled plasma mass spectrometry}

Total metals were dissolved following a procedure based on US EPA Method 3052 (USEPA, 1995). In brief, Teflon filters were cut in half using ceramic blades and then digested in a 2:1 mixture of concentrated nitric and hydrochloric acid (TraceMetal Grade, Fisher Chemical) using a MARS 6 microwave assisted digestion system (CEM Corporation, Matthews, NC) at $200^{\circ} \mathrm{C}$ for $13 \mathrm{~min}$. Extracts were filtered $(0.45 \mu \mathrm{m}$ PTFE) and analyzed for metals using a Thermo $\mathrm{X}$-Series II quadrupole inductively coupled plasma mass spectrometry (ICP-MS) instrument (Thermo Fisher Scientific Inc., Waltham, MA, USA). The instrument was calibrated against IV-ICPMS-71A ICP-MS standard (Inorganic Ventures) at concentrations ranging from 0.1 to $50 \mathrm{ppb}$. The reported data are field blank subtracted and converted to metal concentrations $\left(\mu \mathrm{g} \mathrm{m}^{-3}\right)$ using total filter area, extraction volume, and sampled air volume. The uncertainty was propagated using the average field blank, the standard deviation of the field blanks, and $10 \%$ of the metal concentration. Results are reported only for metals for which the concentrations are greater than the sum of mean field blank levels plus 3 times the standard deviation of the field blank.

\subsubsection{Organic species by gas chromatography mass spectrometry}

All glassware used in preparing filter extracts was prewashed and baked at $500^{\circ} \mathrm{C}$. Source sample filters were subsampled prior to organic species characterization. Filter subsamples were spiked with a suite of isotopically labeled internal standards which were used in quantification: pyrene- $\mathrm{D}_{10}$, benz(a)anthracene- $\mathrm{D}_{12}$, cholestane- $\mathrm{D}_{4}$, pentadecane- $\mathrm{D}_{32}$, eicosane- $\mathrm{D}_{42}$, tetracosane$\mathrm{D}_{50}$, triacontane- $\mathrm{D}_{62}$, dotriacontane- $\mathrm{D}_{66}$, hexatriacontane$\mathrm{D}_{74}$, levoglucosan- ${ }^{13} \mathrm{C}_{6}$, and cholesterol $\mathrm{D}_{6}$. Each sample was then extracted into a hexane: acetone $(1: 1)$ mixture as described by Al-Naiema et al. (2015). The solvent extracts were subsequently concentrated to a final volume of $100 \mu \mathrm{L}$ using a Turbovap (Caliper Life Sciences, Turbo Vap LV Evaporator) and minivap (Thermo Scientific, Reacti-Vap ${ }^{\text {TM }}$ Evaporator) under high-purity nitrogen (PRAXAIR Inc.). Each analysis batch contained 10 source samples and quality control samples containing two field blanks, one lab blank, and one spike recovery sample. These extracted samples were stored at $-20^{\circ} \mathrm{C}$ until analysis.

Hydroxyl-bearing analytes were analyzed following trimethylsilyl (TMS) derivatization, as described in Stone et al. (2012), which converts active hydrogen atoms to TMS groups, thus eliminating their ability to hydrogen bond (Nolte et al., 2002). Briefly, $10 \mu \mathrm{L}$ of the extract was blown down to complete dryness and reconstituted in $10 \mu \mathrm{L}$ of pyridine (Burdick \& Jackson, Anhydrous), and then $20 \mu \mathrm{L}$ of the silylation agent N,O-bis-(trimethylsilyl)trifluoroacetamide
(Fluka Analytical, $99 \%$ ) was added. The mixture was heated at $70^{\circ} \mathrm{C}$ for $3 \mathrm{~h}$ before instrumental analysis.

Filter extracts were analyzed for organic species using gas chromatography (GC; Agilent Technologies 7890A) coupled to mass spectrometry (MS; Agilent Technologies 5975). The GC-MS instrument was equipped with an Agilent DB-5 column $(30 \mathrm{~m}$ length $\times 0.25 \mathrm{~mm}$ inner diameter $\times 0.25 \mu \mathrm{m}$ film thickness) and electron ionization (EI) source. Helium served as the carrier gas (PRAXAIR Inc.). An aliquot of $3 \mu \mathrm{L}$ was injected operating in the splitless mode following the temperature program described in Stone et al. (2012). Responses of analytes were normalized to the corresponding isotopically labeled internal standard, and five-point linear calibration curves (with correlation coefficients, $R^{2} \geq 0.995$ ) were utilized for the quantification of organic species. Compounds that were not in the standards were measured by assessing the response curve from the compound that is most analogous in structure and retention time. All reported species concentrations were field blank subtracted and had spike recoveries in the range of $\pm 20 \%$ of the expected concentration. Field blank concentrations were low in relation to those in source samples for most molecular markers, averaging $<10 \%$ for three-ring $\mathrm{PAH},<1 \%$ for four-ring or greater $\mathrm{PAH},<5 \%$ for hopanes in fossil fuel emissions samples (except for the zigzag kiln in which was at $<45 \%$ ), $<1 \%$ for levoglucosan in biofuel emission samples, and $<10 \%$ for stigmasterol in dung burning emission samples. $n$-Alkane concentrations in field blanks averaged $50 \%$ of the concentrations measured in source emissions, which is reflected in many corresponding EFs being below detection limits and having large relative uncertainties. The analytical uncertainties for the measured species were propagated from the standard deviation of the field blanks and $20 \%$ of the measured concentration.

\subsection{Emission factor calculation}

A field-deployable, Fourier transform infrared (FTIR) spectrometer and whole-air sampling with gas chromatography were used to quantify mixing ratios of up to 80 gases, including $\mathrm{CO}, \mathrm{CO}_{2}$, acid gases $(\mathrm{HCl}, \mathrm{HF}$, etc.), and volatile organic compounds as described by Stockwell et al. (2016). The carbon mass balance approach was used to determine fuel-based EFs for gases, in units of mass of pollutant per kilogram of fuel burned $\left(\mathrm{g} \mathrm{kg}^{-1}\right)$ (Stockwell et al., 2016). $\mathrm{EFs}$ for $\mathrm{CO}\left(\mathrm{EF}_{\mathrm{CO}}\right)$ were converted to $\mathrm{EFs}$ for fine particle mass $\left(\mathrm{EF}_{\mathrm{PM}_{2.5}}\right)$ by the ratio of filtered PM mass $\left(\mathrm{M}_{\mathrm{PM}}\right)$ and the corresponding mass of $\mathrm{CO}\left(\mathrm{M}_{\mathrm{CO}}\right)$ drawn through the filter that was measured in series by FTIR, following Eq. (1).

$\mathrm{EF}_{\mathrm{PM}_{2.5}}=\frac{\mathrm{M}_{\mathrm{PM}}}{\mathrm{M}_{\mathrm{CO}}} \times \mathrm{EF}_{\mathrm{CO}}$

The $\mathrm{EF}_{\mathrm{CO}}$ used in this calculation were calculated to coincide with filter sampling times and thus may differ slightly from those reported by Stockwell et al. (2016). These $\mathrm{EF}_{\mathrm{CO}}$ were calculated using major carbon-containing species in the 


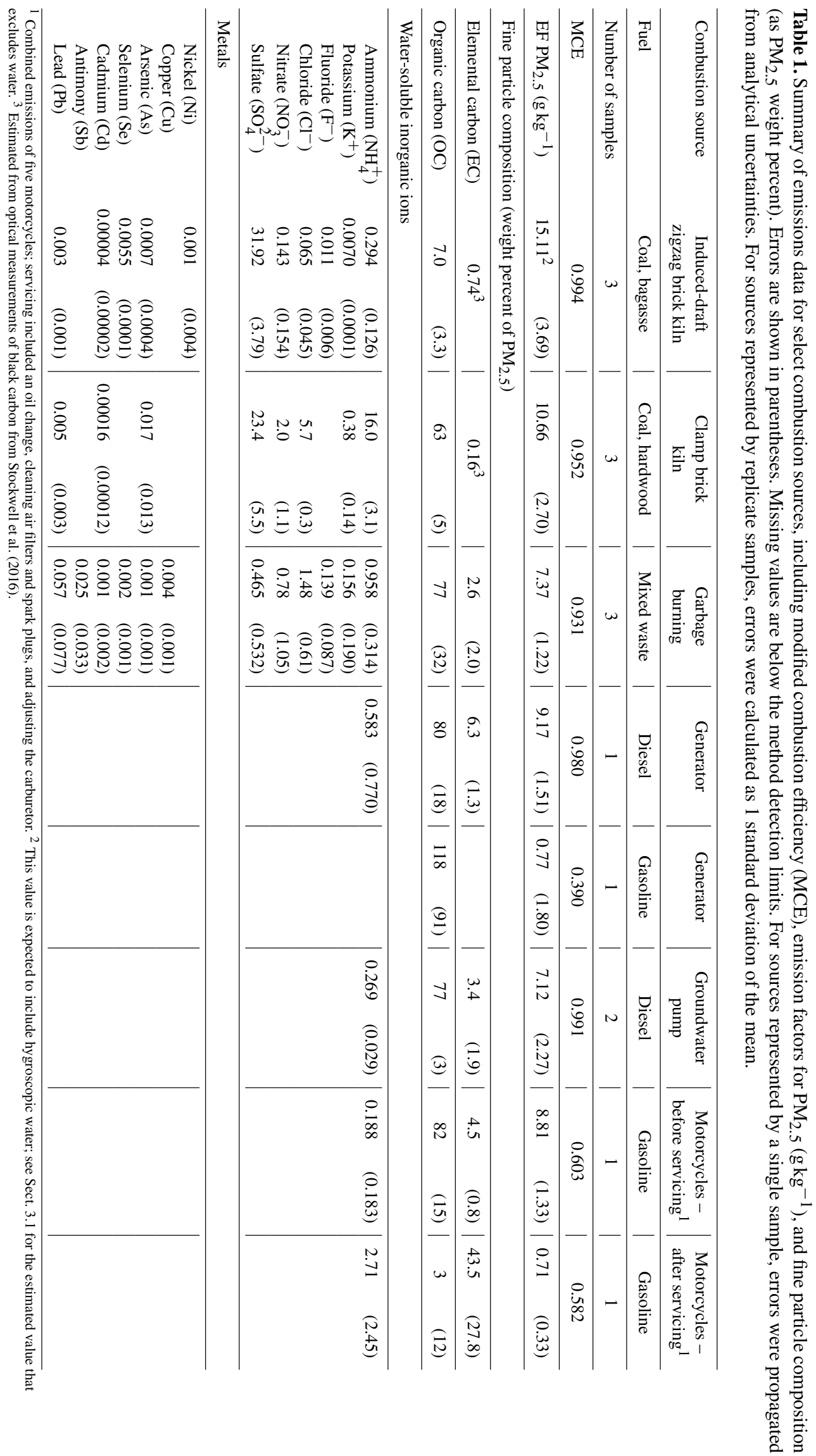


Table 2. Summary of emissions data for select biofuel combustion sources, including modified combustion efficiency (MCE), emission factors for $\mathrm{PM}_{2.5}\left(\mathrm{~g} \mathrm{~kg}^{-1}\right)$, and fine particle composition (as $\mathrm{PM}_{2.5}$ weight percent). Errors are shown in parentheses. Missing values are below the method detection limits. For sources represented by a single sample, errors were propagated from analytical uncertainties. For sources represented by replicate samples, errors were calculated as 1 standard deviation of the mean.

\begin{tabular}{|c|c|c|c|c|c|c|c|c|}
\hline Combustion source & \multicolumn{2}{|c|}{$\begin{array}{l}\text { Traditional mud } \\
\text { cooking stove }\end{array}$} & \multicolumn{2}{|c|}{$\begin{array}{l}\text { Traditional mud } \\
\text { cooking stove }\end{array}$} & \multicolumn{2}{|c|}{ Agricultural fire } & \multicolumn{2}{|c|}{ Open burning } \\
\hline Fuel & \multicolumn{2}{|c|}{ Wood } & \multicolumn{2}{|c|}{ Wood, dung } & \multicolumn{2}{|c|}{ Crop residues ${ }^{1}$} & \multicolumn{2}{|c|}{ Dung, twigs } \\
\hline Number of samples & \multicolumn{2}{|c|}{2} & \multicolumn{2}{|c|}{2} & \multicolumn{2}{|c|}{1} & \multicolumn{2}{|c|}{1} \\
\hline MCE & \multicolumn{2}{|c|}{0.931} & \multicolumn{2}{|c|}{0.919} & \multicolumn{2}{|c|}{0.934} & \multicolumn{2}{|c|}{0.861} \\
\hline $\mathrm{EF} \mathrm{PM}_{2.5}\left(\mathrm{~g} \mathrm{~kg}^{-1}\right)$ & 7.97 & $(3.80)$ & 14.73 & $(0.33)$ & 11.48 & $(1.92)$ & 20.00 & $(3.06)$ \\
\hline \multicolumn{9}{|c|}{ Fine particle composition (weight percent of $\mathrm{PM}_{2.5}$ ) } \\
\hline Elemental carbon (EC) & 14 & (5) & 5.1 & $(2.3)$ & 8.5 & $(1.94)$ & 0.43 & $(0.13)$ \\
\hline Organic carbon (OC) & 52 & $(5)$ & 61 & (10) & 55 & (13) & 65 & (7) \\
\hline \multicolumn{9}{|c|}{ Water-soluble inorganic ions } \\
\hline Sodium $\left(\mathrm{Na}^{+}\right)$ & 0.048 & $(0.066)$ & 0.385 & $(0.350)$ & & & & \\
\hline Ammonium $\left(\mathrm{NH}_{4}^{+}\right)$ & 1.12 & $(0.44)$ & 4.46 & $(1.25)$ & 2.54 & $(0.77)$ & 1.854 & $(0.383)$ \\
\hline $\operatorname{Potassium}\left(\mathrm{K}^{+}\right)$ & 1.78 & $(0.04)$ & 0.520 & $(0.083)$ & 7.22 & $(1.62)$ & 0.804 & $(0.200)$ \\
\hline Fluoride $\left(\mathrm{F}^{-}\right)$ & 0.081 & $(0.016)$ & 0.039 & (0.009) & & & 0.018 & $(0.022)$ \\
\hline Chloride $\left(\mathrm{Cl}^{-}\right)$ & 3.20 & $(1.07)$ & 8.58 & $(0.86)$ & 10.01 & (2.17) & 3.709 & (0.679) \\
\hline Nitrate $\left(\mathrm{NO}_{3}^{-}\right)$ & 0.423 & $(0.125)$ & 0.209 & $(0.216)$ & 2.50 & $(0.62)$ & 0.541 & $(0.140)$ \\
\hline Sulfate $\left(\mathrm{SO}_{4}^{2-}\right)$ & 0.334 & (0.194) & 0.456 & $(0.040)$ & 0.415 & $(0.818)$ & 0.297 & $(0.269)$ \\
\hline \multicolumn{9}{|l|}{ Metals } \\
\hline Nickel (Ni) & & & & & 0.017 & $(0.012)$ & 0.005 & (0.004) \\
\hline Copper $(\mathrm{Cu})$ & 0.005 & $(0.004)$ & 0.001 & $(0.001)$ & & & & \\
\hline Arsenic (As) & 0.004 & $(0.002)$ & 0.001 & $(0.000)$ & & & & \\
\hline Selenium (Se) & 0.006 & $(0.004)$ & & & & & & \\
\hline Cadmium (Cd) & 0.002 & $(0.002)$ & 0.001 & $(0.000)$ & 0.001 & $(0.000)$ & 0.001 & (0.000) \\
\hline Antimony (Sb) & $0.005^{2}$ & $(0.006)$ & & & & & & \\
\hline Lead $(\mathrm{Pb})$ & 0.007 & $(0.007)$ & 0.004 & $(0.001)$ & & & & \\
\hline
\end{tabular}

${ }^{1}$ Rice, wheat, mustard, lentil, and grasses. ${ }^{2}$ Plastic was used to ignite this fire.

mass balance equation: $\mathrm{CO}_{2}, \mathrm{CO}, \mathrm{CH}_{4}, \mathrm{EC}$, and $\mathrm{OC}$. $\mathrm{EFs}$ for $\mathrm{PM}$ components were calculated as the product of $\mathrm{EF}_{\mathrm{PM}_{25}}$ and the component's mass fraction in $\mathrm{PM}_{2.5}$. Uncertainties in EFs were propagated from the relative error in $\mathrm{EF}_{\mathrm{CO}}$, conservatively estimated to be $5 \%$ (Stockwell et al., 2016) and the analytical uncertainty of $\mathrm{EF}_{\mathrm{PM}_{2.5}}$ and the particle-phase species.

\subsection{Modified combustion efficiency}

The modified combustion efficiency (MCE), calculated as $\mathrm{MCE}=\Delta \mathrm{CO}_{2} /\left(\Delta \mathrm{CO}+\Delta \mathrm{CO}_{2}\right)$, was used as an indicator of the relative amount of flaming combustion (MCE $>0.98$ $0.99)$ to smoldering combustion $(\sim 0.75-0.85)$ (McMeeking et al., 2009). Notably, the filter-integrated MCE values reported herein correspond to the average MCE over the duration of filter sample collection. These values differ slightly from those reported by Stockwell et al. (2016), who analyzed the same sources over different time periods.

\section{Results and discussion}

The 41 source samples reported herein are summarized in Table S1 by source category, specific emission source, fuels, and fire numbers. EFs for particle-phase species, including $\mathrm{PM}_{2.5}$, OC, EC, eight inorganic ions, seven metals (for 28 of 41 samples), and 68 organic species are reported in Table S3. For each source category, Tables 1-2 summarize the best estimate of $\mathrm{EF}_{\mathrm{PM}_{2.5}}$ and $\mathrm{PM}_{2.5}$ composition, including $\mathrm{OC}, \mathrm{EC}$, water-soluble inorganic ions, and metals as mass fractions for fossil/waste-fueled and bio-fueled combustion sources, respectively. Tables 3-4 summarize the best estimates of organic species emissions normalized to OC for fossil/wastefueled and bio-fueled combustion sources, respectively. The 


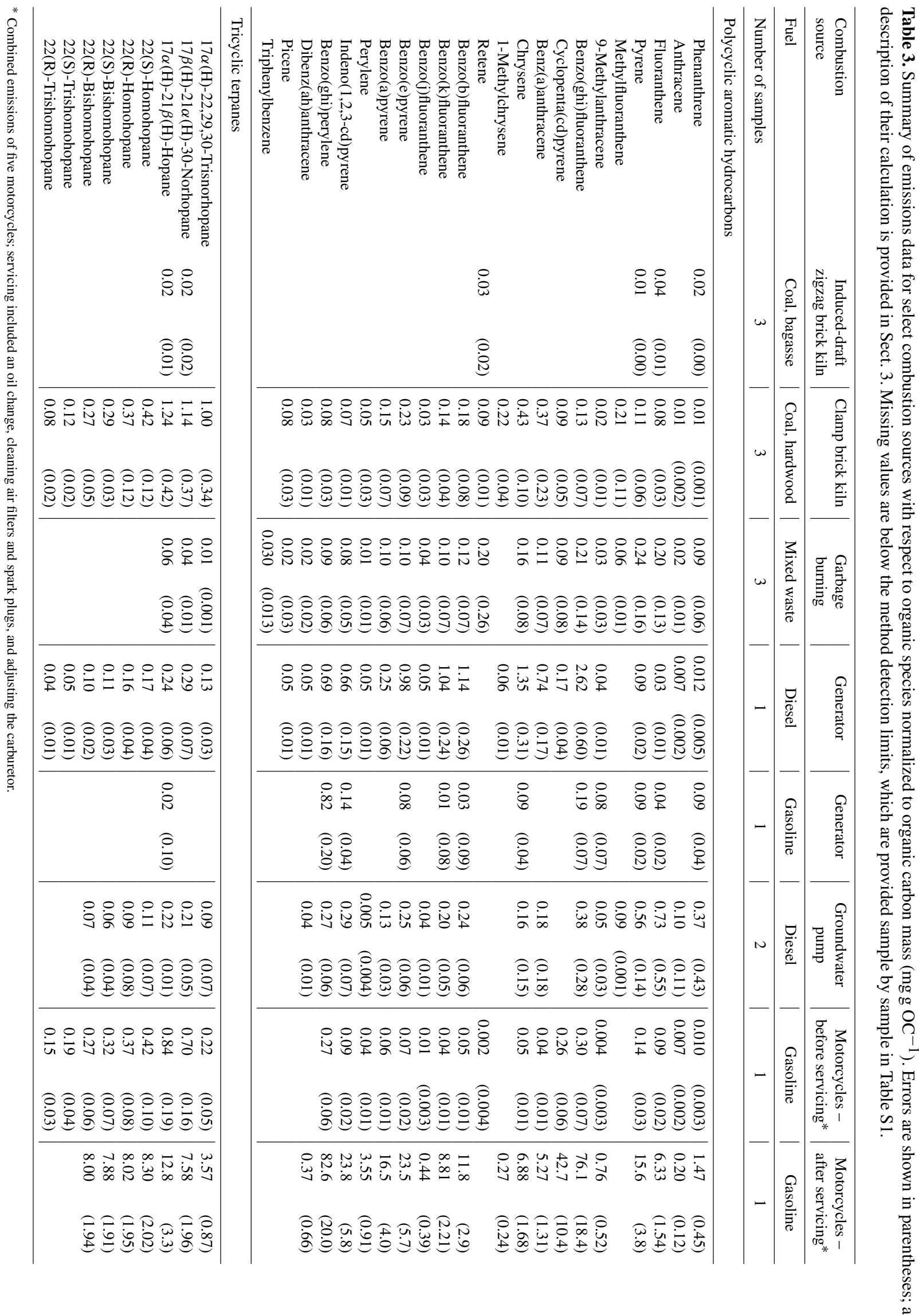




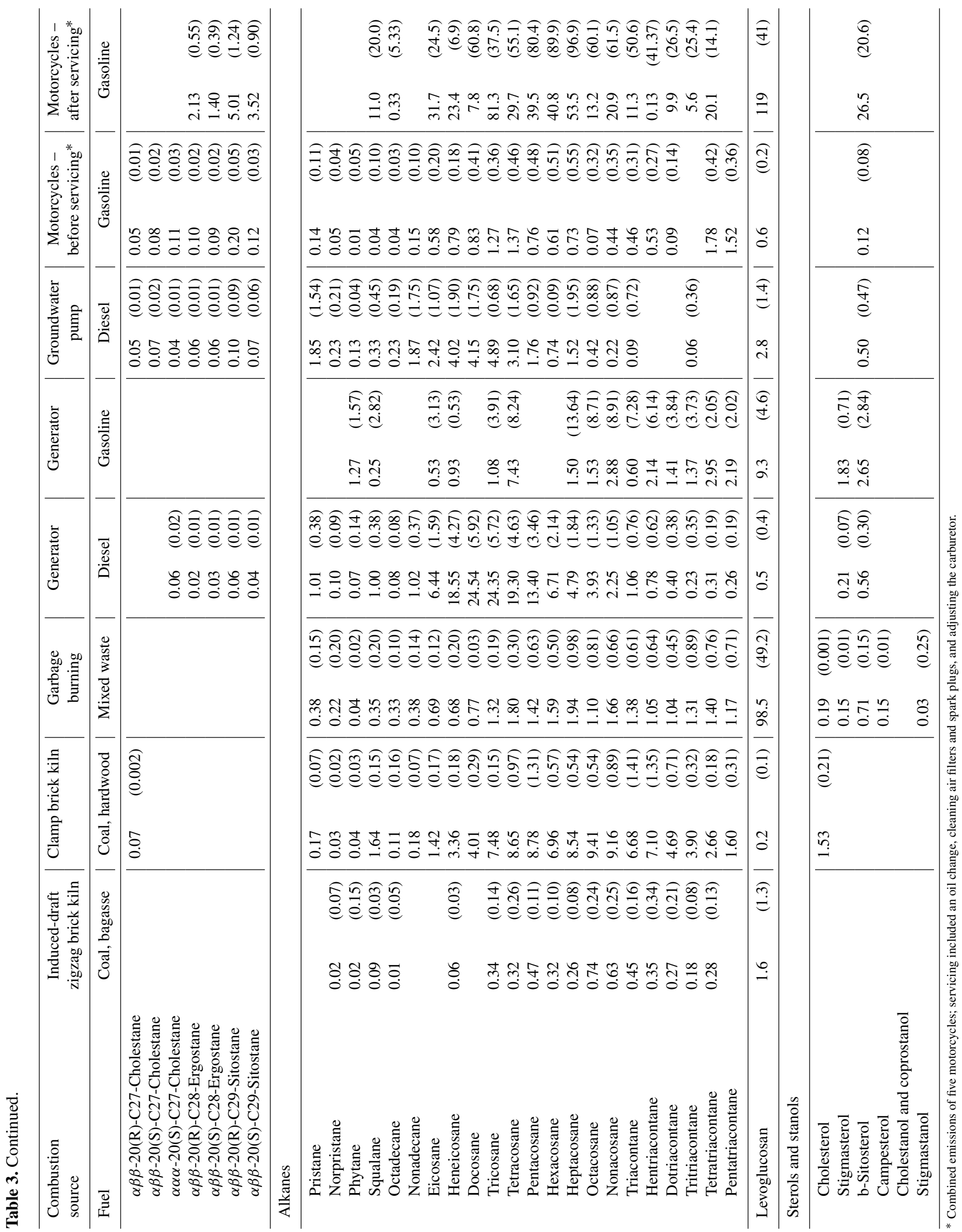


best estimates of source emissions were determined as the mean of available replicate measurements of a source category or the most representative (or only available) sample from a source. For sources represented by a single sample, errors were propagated from analytical uncertainties. For sources represented by replicate samples, errors were calculated as 1 standard deviation of the mean. In cases when components were not detected in all replicate samples, $\mathrm{PM}_{2.5}$ or OC-normalized concentrations were averaged among the available data. This calculation reflects that species go undetected due to low filter loadings, rather than differences in species mass fractions within a source category.

The reported EFs reflect partially diluted emissions, as plumes were sampled several meters downwind of the source after cooling to ambient temperature. The average $\mathrm{PM}_{2.5}$ mass concentrations measured in source samples (Table $\mathrm{S} 1)$ ranged from 45 to $82600 \mu \mathrm{g} \mathrm{m}^{-3}$ and averaged $10900 \mu \mathrm{g} \mathrm{m}^{-3}$. High PM concentrations were required to capture source signatures in situ; however, the combination of high PM levels with large emissions of semi-volatile OC (SVOC) can increase PM mass and OC emissions due to the partitioning of SVOC to the particle phase (Lipsky and Robinson, 2006). Thus, $\mathrm{EF}_{\mathrm{PM}_{2.5}}$ and $\mathrm{EF}_{\mathrm{OC}}$ depend on the dilution ratio and chemical composition of the source emissions, while EC is not affected (Lipsky and Robinson, 2006). The partitioning effect may add some uncertainty to EF comparisons between sources in this study and between studies in the literature in general, since sampling systems cannot be designed to sample all sources at the same concentration and concentrations are often not reported with EF. We document the sample concentrations in Table S1 in part to help remedy this. Furthermore, different concentrations may be relevant for different study objectives. For instance, near-source high concentrations may be preferred for cooking fire exposure assessment. Also, sampling filters at high PM concentrations provides a better measure of total carbon (including SVOC and PM) since the capability to measure the evaporated SVOC in the gas phase is uncommon. On the other hand, source apportionment may be best based on ratios between low-volatility components.

To estimate the potential influence of background PM on the source emissions, the sampled concentrations of PM and OC were compared to background levels. The $\mathrm{PM}_{2.5}$ concentrations in source plumes (Table S1) were compared to the average $\mathrm{PM}_{2.5}$ concentration measured in Kathmandu at a suburban site, named Bode $\left(27.689^{\circ} \mathrm{N}, 85.395^{\circ} \mathrm{E}\right)$, in the westerly outflow of Kathmandu city (Sarkar et al., 2016) where, during NAMaSTE, the ambient $\mathrm{PM}_{2.5}$ concentration at Bode ranged from 30 to $95 \mu \mathrm{g} \mathrm{m}^{-3}$ and averaged ( \pm standard deviation) $62 \pm 19 \mu \mathrm{g} \mathrm{m}^{-3}$. Using this method, we estimate that in $90 \%$ of the studied plumes, background PM contributed $<8 \%$ of the collected PM. And in $65 \%$ of the studied plumes, background contributed $<4 \%$ of the collected PM. For some sources with low PM emissions, background PM was more influential, contributing 10-20\% for

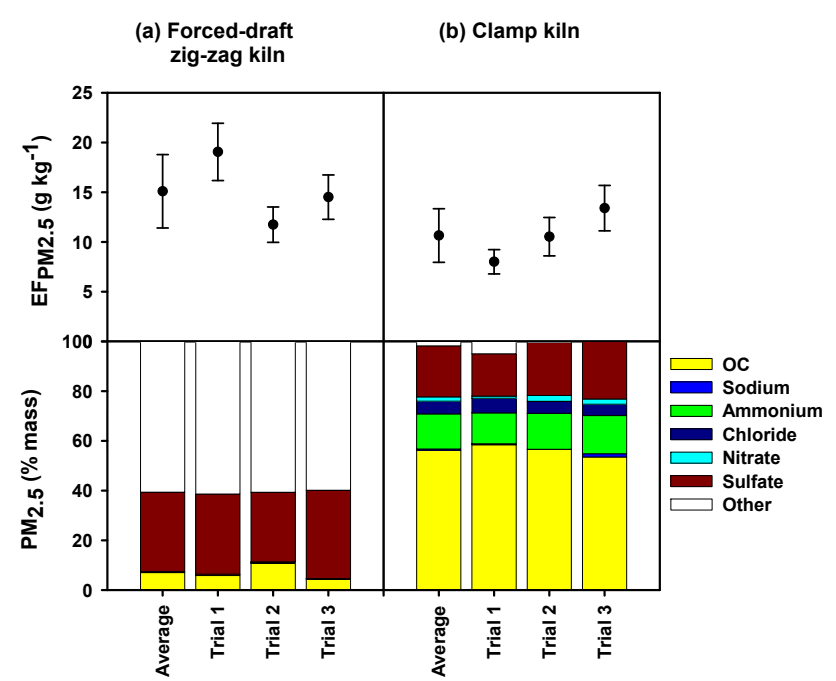

Figure 1. $\mathrm{EF}_{\mathrm{PM}_{2.5}}$ and $\mathrm{PM}_{2.5}$ composition (as percent by mass) for forced-draft zigzag kilns (a) and clamp kilns (b). For the average $\mathrm{EF}_{\mathrm{PM}_{2.5}}$, error bars for averages correspond to 1 standard deviation, while those for individual trials show the analytical uncertainty. EC was not detected in brick kiln emissions; optical measurements of BC from Stockwell et al. (2016) are provided in Table 1.

emissions from biobriquettes burned in a forced-draft stove with an electrical charger and hardwood burned in forceddraft cooking stoves and $30 \%$ for motorcycles after servicing. The gasoline generator emissions were sufficiently close to ambient PM concentrations, such that source emissions could not be defined. In addition, the sampled OC concentrations were compared to background OC levels estimated from organic aerosol (OA) measured by AMS (Goetz et al., 2018a) for all sources excluding generators and the background was estimated to contribute $0.02-2.8 \%$ (averaging $0.7 \%$ ) of the OC collected.

Particle-phase EF are complementary to those reported by Stockwell et al. (2016) for organic and inorganic gases and aerosol optical properties. A comparison of the EF reported herein to the size and chemically resolved emission factors by AMS will be provided by Goetz et al. (2018a). Together, these datasets provide a more thorough and in some cases initial characterization of gas and particle emissions from many important combustion sources in South Asia. EF and PM composition are discussed in the following subsections by source category, followed by a description of their potential applications.

\subsection{Zigzag kiln}

The induced-draft zigzag kiln, fueled primarily by coal with some bagasse, had a mean fuel-based $\mathrm{EF}_{\mathrm{PM}_{2.5}}$ of $15.1 \pm 3.7 \mathrm{~g} \mathrm{~kg}^{-1}$ across three replicate samples. The corresponding MCE was very high at 0.994, indicative of flaming and relatively complete combustion. Major components con- 
tributing to PM mass included OC (ranging from 4 to $11 \%$, averaging $7 \%$ ) and sulfate (ranging from 27 to $35 \%$, averaging $32 \%$ ) (Table 1; Fig. 1a), where sulfate was expected to be primarily in the form of sulfuric acid as described below. The majority of the $\mathrm{PM}_{2.5}$ mass was not explained by the species measured. Metals associated with clay - aluminum, iron, and titanium - were not detected, indicating that brick dust was not a major part of the unexplained $\mathrm{PM}_{2.5}$ mass. Other water-soluble ions had minor mean contributions to $\mathrm{PM}_{2.5}$ mass: ammonium $(0.29 \%)$, fluoride $(0.011 \%)$, chloride $(0.065 \%)$, and nitrate $(0.14 \%)$. The deficit of cationic counterions for sulfate (corresponding to $<4 \%$ neutralization of sulfate) suggests that the majority of sulfate was in the form of sulfuric acid, although these two species are indistinguishable by the extraction and ion chromatography methods applied. Sulfuric acid is a very hygroscopic compound that spontaneously takes up water at low relative humidity near $0 \%$ (Jacobson, 2005). Because sulfuric acid is prone to hydration in the relative humidity conditions of our gravimetric analysis (34 $\pm 12 \%$, Sect. 2.2.1) and the condensation of water droplets on Teflon filters was visually observed for samples from this source, it is expected that particle-bound water accounts for some of the unexplained $\mathrm{PM}_{2.5}$ mass. Since the gravimetric methods utilized for the determination of $\mathrm{EF}_{\mathrm{PM}_{2.5}}$ include particle-bound water (Tsyro, 2005), we use the sum of the measured $\mathrm{PM}_{2.5}$ components and assume an $\mathrm{OC}$ to organic matter conversion factor of 1.4 to estimate the lower limit of $\mathrm{EF}_{\mathrm{PM}_{2.5}}$ (which excludes the maximum possible amount of hygroscopic water) to be $6.3 \mathrm{~g} \mathrm{~kg}^{-1}$.

The combination of particle-phase ion measurements and gas-phase measurements by Stockwell et al. (2016) provides a means of determining gas-particle distributions of some elements. On a molar basis, less than $1 \%$ of the measured $\mathrm{F}$ and $\mathrm{Cl}$ were detected in the particle phase, with $>99 \%$ in the gas phase as $\mathrm{HF}$ and $\mathrm{HCl}$, respectively; this signals very fresh emissions as discussed in Stockwell et al. (2014). The F emitted is likely to have originated in the clay material used to make the bricks (EPA, 1996). On a molar basis, $20 \%$ of sulfur was emitted in the particle phase as sulfate $\left(\mathrm{EF}_{\mathrm{SO}_{4}} 4.9 \mathrm{~g} \mathrm{~kg}^{-1}\right)$, while the majority of sulfur emissions were gaseous $\mathrm{SO}_{2}\left(\mathrm{EF}_{\mathrm{SO}_{2}} 12.7 \mathrm{~g} \mathrm{~kg}^{-1}\right.$; Stockwell et al., 2016), indicating that within 1-2 m of the stack, a substantial fraction of $\mathrm{SO}_{2}$ had been oxidized to form sulfate.

OC comprised an appreciable fraction of PM mass and EF ${ }_{\text {OC }}$ averaged $1.0 \mathrm{~g} \mathrm{~kg}^{-1}$. The $\mathrm{EF}_{\mathrm{OC}}$ was within $10 \%$ of the $\mathrm{EF}$ for $\mathrm{OA}$ reported as brown carbon $\left(\mathrm{EF}_{\mathrm{BrC}}\right)$, estimated by photoacoustic extinctiometry (PAX; Stockwell et al., 2016), suggesting that the mass absorption coefficient by Stockwell et al. (2016) used $\left(0.98 \mathrm{~m}^{2} \mathrm{~g}^{-1}\right)$ was reasonably appropriate for this source and that there was no substantial positive artifact due to the adsorption of semi-volatile organic compounds in the filter-based OC measurement. EC was not detected by thermal-optical analysis, and thus the optically determined $\mathrm{EF}_{\mathrm{BC}}$ at $0.112 \mathrm{~g} \mathrm{~kg}^{-1}$ for this source (Stockwell et al., 2016) is recommended to estimate the soot component of the smoke. The BC-to-total-carbon (TC) ratio is therefore 0.10 , indicating predominantly organic emissions.

The carbon component of the organic species measured by GC-MS accounted for an average of $0.58 \%$ of OC. The most abundant individual species measured was levoglucosan, a well-established tracer of biomass burning (Simoneit et al., 1999), for which the mean EF was $1.69 \mathrm{mg} \mathrm{kg}^{-1}$. This EF is markedly lower than those reported for open biomass fires (Christian et al., 2010) or cooking stoves (Sheesley et al., 2003) reported previously and in this work (Sect. 3.7 and Table S3). Likewise, the levoglucosan contribution to PM mass is $<0.02 \%$, compared to an average of $9 \%$ from the biomass-fueled cooking stoves in this study (Table S3). The small EF and mass fractions of levoglucosan reflect the relatively small amount of wood burned in this zigzag kiln relative to coal. Very low levels of hopanes and low-molecular weight PAHs with three rings were observed (Table 3), while higher-molecular weight PAHs, including picene, a proposed tracer of coal combustion (Oros and Simoneit, 2000), were not detected. Low levels of organic species are consistent with the high MCE value and reflect relatively complete combustion of the coal.

Significant differences in emissions were found from the induced-draft zigzag kiln compared to prior studies (Table 5). First, the mean $\mathrm{EF}_{\mathrm{PM}_{2.5}}$ for the induced-draft zigzag kiln $\left(15.1 \pm 3.7 \mathrm{~g} \mathrm{~kg}^{-1}\right)$ was considerably higher than the $\mathrm{EF}_{\mathrm{PM}_{2.5}}$ reported by Weyant at al. (2014) for induced-draft zigzag kilns fueled with coal in India $\left(0.6-1.2 \mathrm{~g} \mathrm{~kg}^{-1}\right)$. Notably, measurements by Weyant at al. (2014) were sampled within the stack and then diluted, compared to natural dilution that occurred 1-2 $\mathrm{m}$ downwind. Because the kiln emissions in this study were sampled downwind of the stack after they had cooled and diluted naturally, rather than pulled from it, our PM samples are likely to have undergone chemical evolution that occurs above the sampling port and/or quickly postemission (e.g., conversion of $\mathrm{SO}_{2}$ to sulfate), which could contribute to higher measurements of PM mass. Christian et al. (2010) used similar sampling methods to this study and estimated $\mathrm{PM}_{2.5}$ mass from the sum of the particle-phase measurements of OC, EC, metals, and ions (but not sulfate) for two batch-style brick kilns fueled primarily by biomass in Mexico; their reconstructed $\mathrm{PM}_{2.5}$ mass totaled 1.24 and $1.96 \mathrm{~g} \mathrm{~kg}^{-1}$ and is in good agreement with the sum of EF for OC, EC, metals, and ions (excluding sulfate) for the zigzag kiln, which ranged from 0.67 to $1.33 \mathrm{~g} \mathrm{~kg}^{-1}$. Thus, the difference in $\mathrm{EF}_{\mathrm{PM}_{2.5}}$ is expected to be due to sulfate and hygroscopic water. Second, the observed EC : TC ratios are much lower than the range of values from 0.75 to 0.90 reported previously for induced-draft zigzag kilns in South Asia (Weyant et al., 2014) and from 0.84 to 0.89 for two batch-style kilns in Mexico (Christian et al., 2010). In comparison, the smoke emitted from the zigzag kiln in this study was qualitatively described as white, with puffs of black smoke emitted only when fuel was added. With total carbon emissions comparable across this study (0.63-1.26 $\left.\mathrm{g} \mathrm{kg}^{-1}\right)$ 
and those by Weyant et al. (2014, $0.08-0.67 \mathrm{~g} \mathrm{~kg}^{-1}$ ) and Christian et al. $\left(2010,0.669-1.783 \mathrm{~g} \mathrm{~kg}^{-1}\right)$, the main reasons for the increased $\mathrm{EF}_{\mathrm{PM}_{2.5}}$ from the induced-draft zigzag kiln in Nepal are the high emissions of sulfate (likely in the form of sulfuric acid) and hygroscopic water.

\subsection{Clamp kiln}

The clamp kiln studied produced a mean $\mathrm{EF}_{\mathrm{PM}_{2.5}}$ of $10.7 \pm 2.7 \mathrm{~g} \mathrm{~kg}^{-1}$ across three replicate tests. The average MCE was 0.952 , reflecting less complete combustion than the induced-draft zigzag kiln (Stockwell et al., 2016). On average, the $\mathrm{PM}_{2.5}$ emitted from the clamp kiln included the following major components: OC $(63.2 \%)$, sulfate $(23.4 \%)$, ammonium (16.0\%), chloride (5.7\%), and nitrate $(2.0 \%)$ (Table 1; Fig. 1b). Minor components included BC $(0.2 \%)$, and potassium $(0.2 \%)$. The sum of $\mathrm{OC}, \mathrm{BC}$, and measured inorganic ions exceeded the measured $\mathrm{PM}_{2.5}$ mass by an average of $11 \%$, which is within the propagated uncertainty of the analytical measurements. Unlike the zigzag kiln, there was no evidence of hygroscopic water contributions to PM mass; this is because in the clamp kiln emissions, the sulfate was fully neutralized by ammonium (possibly from the biomass) to form ammonium sulfate, which deliquesces at 79-80 \% RH (Martin, 2000), well above the RH during gravimetric mass measurements. Neither particulate fluoride nor gas-phase HF were detected from the clamp kiln. Chloride, however, was a significant component of PM, but gaseous $\mathrm{HCl}$ was below the FTIR detection limit and other chlorinated organic gases (e.g., $\mathrm{CH}_{3} \mathrm{Cl}$ ) were not greater than background levels (Stockwell et al., 2016).

Emissions of carbonaceous aerosol were the greatest contributor to $\mathrm{PM}_{2.5}$ mass, with an average $\mathrm{EF}_{\mathrm{OC}}$ of $6.77 \mathrm{~g} \mathrm{~kg}^{-1}$. The OC was an average of $95 \%$ water insoluble, characteristic of fresh emissions from fossil fuel combustion. As with the zigzag kiln emissions, EC was not detected by thermaloptical analysis. Consequently, optically determined BC, averaging $0.0172 \mathrm{~g} \mathrm{~kg}^{-1}$ (Stockwell et al., 2016), provides an estimate of the soot component of the smoke and yielded a BC-to-TC ratio of 0.0025 . The $\mathrm{BrC}$ measurement by the PAX yielded an estimated OA (using the same average mass absorption coefficient (MAC) as above) that was only $26 \%$ of our OC, suggesting that the MAC for these emissions was actually lower than average as expected for the low BC / TC ratio (Saleh et al., 2014).

The measured organic species accounted for an average of $9.1 \%$ of the OC. The dominant class of compounds detected was $n$-alkanes, which had an EF of $638 \mathrm{mg} \mathrm{kg}^{-1}$ for carbon numbers ranging from 18 to 35 . The EF for 22 measured PAHs with three to six aromatic rings averaged $18.7 \mathrm{mg} \mathrm{kg}^{-1}$, with the most abundant PAHs being chrysene, benz(a)anthracene, benzo(e)pyrene, and 1methylcrysene. Picene - a molecular marker for coal combustion (Oros and Simoneit, 2000; Zhang et al., 2008) - was detected in all three clamp kiln samples, with an average EF

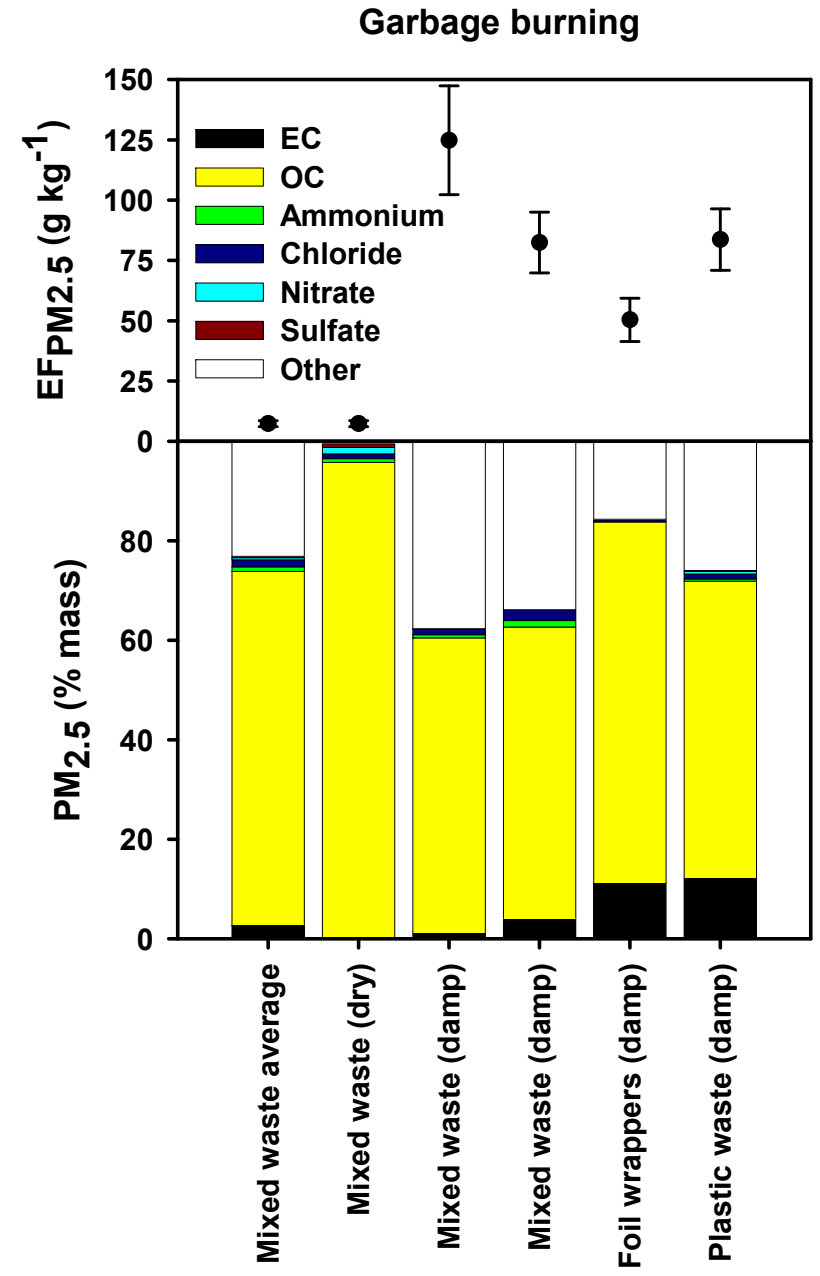

Figure 2. $\mathrm{EF}_{\mathrm{PM}_{2.5}}$ and $\mathrm{PM}_{2.5}$ composition (as percent by mass) for garbage burning. $\mathrm{EF}_{\mathrm{PM}_{2.5}}$ for the combustion of mixed waste under dry conditions was substantially lower than mixed waste burned under damp conditions. The former was considered the best estimate of $\mathrm{EFPM}_{2.5}$ emissions from this source and is shown as the mixedwaste average $\mathrm{EFPM}_{2.5}$ along with the average $\mathrm{PM}_{2.5}$ composition (\% mass) for the three mixed waste burns. Error bars correspond to analytical uncertainties.

of $0.53 \mathrm{mg} \mathrm{kg}^{-1}$. In addition, hopanes that are present in coal and other fossil fuels (Oros and Simoneit, 2000; Zhang et al., 2008) were also detected (Table 3 ). The low emissions of levoglucosan $\left(1.67 \mathrm{mg} \mathrm{kg}^{-1}\right)$ suggest that most of the hardwood had been consumed in the kiln before our sampling began.

In comparison to the batch-style kiln studied by Christian et al. (2010), the clamp kiln had substantially higher emissions of OC and lower MCE, both consistent with less complete combustion (Table 5). Like the zigzag kiln, OC dominated EC in clamp kiln emissions. Clamp kilns were not studied by Weyant et al. (2014), although our $\mathrm{EF}_{\mathrm{PM}_{2.5}}$ exceeded those from all seven kiln designs they studied, likely due to higher emissions of OC and sulfate as described in Sect. 3.1. 


\subsection{Garbage burning}

Emissions from five different garbage burning fires were characterized (Fig. 2). The sample of waste burning at the household level under dry conditions (see Sect. 2.1.2) had an $\mathrm{EF}_{\mathrm{PM}_{2.5}}$ of $7.4 \pm 1.2 \mathrm{~g} \mathrm{~kg}^{-1}$ and an MCE value of 0.980 that indicated primarily flaming combustion. This $\mathrm{EF}_{\mathrm{PM}_{2.5}}$ is similar to prior studies of garbage burning, including (i) waste burning in municipal landfills near Mexico City of $9.8 \pm 5.7 \mathrm{~g} \mathrm{~kg}^{-1}$ (Akagi et al., 2011), (ii) the open burning of military waste that had an average $\mathrm{EF}_{\mathrm{PM}_{2.5}}$ of $19.4 \mathrm{~g} \mathrm{~kg}^{-1}$ (Woodall et al., 2012), assuming that $45 \%$ of the garbage was composed of carbon, following the recommendation of Wiedinmyer et al. (2014), (iii) household waste burning in a burn barrel with an average $\mathrm{EF}_{\mathrm{PM}_{2.5}}$ of 5.3 and $17.5 \mathrm{~g} \mathrm{~kg}^{-1}$ for avid recyclers and non-recyclers, respectively (Lemieux et al., 2000), and (iv) the EF for total suspended particulate of $8 \mathrm{~g} \mathrm{~kg}^{-1}$ (Gerstle and Kemnitz, 1967) for open burning of municipal refuse in the US EPA's Compilation of Air Pollutant Emission Factors (EPA, 1996). Because of the good agreement of this $\mathrm{EF}_{\mathrm{PM}_{2.5}}$ with prior studies, this value is recommended as the emission factor for this source over the results from other garbage burning samples in this study (Table 1). Dry garbage burning is more likely encountered in rural areas where wet organic waste is composted in nearby agricultural fields rather than burned.

Much higher $\mathrm{EF}_{\mathrm{PM}_{2.5}}$ were observed for garbage burning under damp conditions, which is not the typical case but can be encountered at dump sites where the mixture of organic and inorganic waste creates damp conditions, under which the fires smolder for a long time. Wet garbage burning is more likely to occur after rainfall or in urban areas where composting is less common. For these samples, garbage had been dampened by rainfall the previous evening, making it difficult to ignite (requiring newspaper) and causing it to require reignition on occasion (Stockwell et al., 2016). Two samples from the same mixed-waste fire produced $\mathrm{EF}_{\mathrm{PM}_{2.5}}$ values of $124 \pm 23 \mathrm{~g} \mathrm{~kg}^{-1}$ (MCE 0.889) and $82 \pm 13 \mathrm{~g} \mathrm{~kg}^{-1}$ (MCE 0.926). The variation among these samples collected from the same fire is attributed to differences in the fire cycle (i.e., the extent of smoldering vs. flaming). Aluminumfoil-lined bags, burned under the same damp conditions, had an $\mathrm{EF}_{\mathrm{PM}_{2.5}}$ of $50 \pm 9 \mathrm{~g} \mathrm{~kg}^{-1}$ (MCE 0.973), while plastic burning had an $\mathrm{EF}_{\mathrm{PM}_{2.5}}$ of $84 \pm 13 \mathrm{~g} \mathrm{~kg}^{-1}$ (MCE 0.951). These data demonstrate that emissions vary substantially with fuel composition, as shown by the variations between the mixed-garbage and sorted-trash burns as well as prior studies. $\mathrm{EF}_{\mathrm{PM}_{2.5}}$ from garbage burning samples under damp conditions exceeds those burned under dry conditions by factors of 2.5-25. EF for $\mathrm{PM}_{2.5}$ and its components for each garbage burn sample are provided in Table S3. Because of the potential to decrease garbage burning emissions substantially by avoiding burning damp garbage, this trend should be further investigated.
The wide range of $\mathrm{EF}_{\mathrm{PM}_{2.5}}$ observed herein, as evidenced by a relative standard deviation of $63 \%$ across the five garbage burning samples, suggests a high degree of variability across fires, which translates to large uncertainties in estimating emissions from this source. Because global garbage burning estimates of $\mathrm{PM}_{2.5}$ rely upon the EF reported by Akagi et al. (2011) and the US EPA compilation (EPA, 1996) to estimate the global impact of trash burning (Wiedinmyer et al., 2014), variability in $\mathrm{PM}_{2.5}$ emissions is not well-represented and consequently emissions from this source may be either over- or underestimated. Further constraining the impact of garbage burning on ambient PM on national, regional, or global scales requires a better understanding of the amount of garbage burning in addition to the variability in $\mathrm{EF}$ for different fuel composition, moisture content, and burn conditions.

The major element present in $\mathrm{PM}_{2.5}$ emitted from garbage burning was carbon, primarily in the form of OC. The chemical profile of $\mathrm{PM}_{2.5}$ (Table 1; Fig. 2) was estimated from the average emissions of the three mixed household garbage burning samples spanning samples collected under dry conditions $(n=1)$ and wet conditions $(n=2)$ and was $77 \%$ OC, $2.6 \% \mathrm{EC}$, and $1.5 \%$ chloride, with minor contributions $(<1 \%)$ from ammonium, potassium, fluoride, nitrate, and sulfate and no detectable contributions from sodium, calcium, or magnesium (Table 1). OC:EC ratios for mixedgarbage burning under damp conditions were 50 and 15 (EC was below detection limits in the sample burned under dry conditions) and overlapped the range for this ratio reported by Christian et al. (2010) for garbage burning in Mexico. Chlorine in garbage burning is primarily emitted as $\mathrm{HCl}$ and results to a large degree from polyvinylchloride (PVC) plastics (Lemieux et al., 2000; Christian et al., 2010). In agreement with these prior studies, the majority of chlorine emitted from trash burning was initially in the gas phase as $\mathrm{HCl}$ (Stockwell et al., 2016), with $30 \%$ in the particle phase for mixed-garbage burning under damp conditions and $<3 \%$ in the particle phase for mixed-garbage burning under dry conditions. The bulk chemical signatures of burning foil wrappers and plastic were similar to mixed garbage in their dominance of OC, although they had higher mass fractions of EC.

Prior work has demonstrated that garbage burning has a unique signature of metals, making them useful in source identification and apportionment. For combustion sources in and around the Mexico City Metropolitan Area, Christian et al. (2010) reported antimony (Sb) in garbage burning at levels 555 times greater than biomass burning. For garbage burning emissions in Nepal, Sb was detected above field blank levels and method detection limits only in garbage burning emissions (Table 1) and the traditional mud stove cooking fire, in which plastic was used for ignition. These results indicate that this element is unique to garbage burning, particularly plastic. In addition to $\mathrm{Sb}$, mixed-garbage burning emitted $\mathrm{Cu}, \mathrm{Pb}$, and other trace elements. 
1,3,5-Triphenylbenzene (TPB) is proposed as a tracer of garbage burning emissions, due to its specificity to this source, high concentration in source emissions relative to other species, and detection in urban areas where garbage burning occurs (Simoneit et al., 2005). TBP was detected in all five garbage burning samples, with an $\mathrm{EF}_{\mathrm{TPB}}$ of 0.38 $1.87 \mathrm{mg} \mathrm{kg}^{-1}$ for mixed-waste burning, $0.27 \mathrm{mg} \mathrm{kg}^{-1}$ for foil wrappers, and $0.55 \mathrm{mg} \mathrm{kg}^{-1}$ for plastic bags. Meanwhile, TPB was not detected in any other combustion samples in this study, further emphasizing its specificity to garbage burning. Mass normalized emissions of TPB were 12-51 $\mathrm{g} \mathrm{g} \mathrm{PM}^{-1}$ for mixed waste, $5.3 \mu \mathrm{g} \mathrm{PM}^{-1}$ for foil wrappers, and $6.5 \mu \mathrm{g} \mathrm{PM}^{-1}$ for plastic burning. These values fall in the middle of the range of those reported by Simoneit et al. (2005), which were $0.2 \mu \mathrm{g} \mathrm{PM}^{-1}$ for new polyethylene bags in the US and 57-208 $\mu \mathrm{g} \mathrm{PM}^{-1}$ for new plastic bags, roadside litter, and landfill trash in Chile. These comparisons demonstrate that TPB mass fractions can span 3 orders of magnitude but may cover a much narrower range when measured in a single region. Thus, in using this tracer for source apportionment, it is recommended to use in situ emission factors developed within the region of study and that $\mathrm{Sb}$ and TPB be used in concert to provide inorganic and organic constraints on estimates of emissions from garbage burning.

The carbon fraction of the organic species measured in emissions from mixed-garbage burning accounted for an average of $12 \%$ of the observed OC, with the largest contributions from levoglucosan $(9.8 \%)$ marking the inclusion of cellulosic materials in the garbage, $n$-alkanes $(1.8 \%)$, PAHs $(0.2 \%)$, sterols $(0.1 \%)$, and hopanes $(<0.01 \%)$. The dominance of $n$-alkanes in garbage burning emissions is consistent with prior work by Simoneit et al. (2005) in Chile. The even-carbon preference characteristic of $n$-alkanes in polyethylene was lost during combustion due to thermal cracking (Simoneit et al., 2005), yielding carbon preference index (CPI) values in the range of 0.6-1.1.

EFs for the 23 measured PAHs across the five garbage burns ranged from 15 to $152 \mathrm{mg} \mathrm{kg}^{-1}$, with the minimum corresponding to mixed-waste burning in the Tarai and the maximum corresponding to plastic waste burning. Emissions of particle-phase PAH from garbage burning are notably high from garbage burned under damp conditions in comparison to other sources (Ravindra et al., 2008), with maximum levels exceeding one- or two-pot traditional stoves in this study (38-56 $\mathrm{m} \mathrm{kg}^{-1}$; Table S3) and the open burning of scrap tires $\left(56 \mathrm{mg} \mathrm{kg}^{-1}\right.$; Downard et al., 2015). Although the absolute $\mathrm{EF}_{\mathrm{PAH}}$ were high, $\mathrm{PAH}$ accounted for $<0.2 \%$ of $\mathrm{PM}_{2.5}$ mass, consistent with the other non-fossil fuel combustion sources in this study (Table S3). The combination of high PAH emissions and the health impacts of these compounds (e.g., carcinogenicity, teratogenicity) highlight the health risks associated with garbage burning. A number of other toxic, carcinogenic, and mutagenic chemicals associated with garbage burning that were not measured here, such as polychlorinated dibenzo- $p$-dioxins, polychlorinated dibenzofurans (Lemieux et al., 2000), and nitro-PAH (Lee et al., 1995), also contribute to the hazards associated with exposure to garbage burning emissions.

\subsection{Diesel and petrol generators}

$\mathrm{EF}_{\mathrm{PM}_{2.5}}$ was $9.2 \pm 1.5 \mathrm{~g} \mathrm{~kg}^{-1}$ for the diesel generator and $0.8 \pm 1.8 \mathrm{~g} \mathrm{~kg}^{-1}$ for the petrol powered generator (Fig. 3a; Table S3). $\mathrm{PM}_{2.5}$ concentrations in the sampled smoke plume from the petrol generator were not significantly greater than background PM levels, resulting in a high uncertainty. The observed EFs are near the average values reported in the EPA Emission Factors (AP 42) for uncontrolled gasoline and diesel industrial engines of 6.0 and $2.0 \mathrm{~g} \mathrm{~kg}^{-1}$, respectively (EPA, 1996). Recent studies have shown consistently lower $\mathrm{EF}_{\mathrm{PM}_{2.5}}$ for US military diesel generators that exhibited an average ( \pm standard deviation) of $1.2 \pm 0.6 \mathrm{~g} \mathrm{~kg}^{-1}$ (Zhu et al., 2009). Although limited to one sample, the rented diesel generator studied in Nepal had a high $\mathrm{EF}_{\mathrm{PM}_{2.5}}$ value in comparison to other studies.

Chemically, OC and EC accounted for the greatest fraction of $\mathrm{PM}_{2.5}$ mass (Fig. 3a). For the diesel generator, $\mathrm{PM}_{2.5}$ was $80 \%$ OC and $6 \%$ EC. The predominance of OC and EC in diesel generator emissions is consistent with prior studies that showed their mass contributions in excess of $83 \%$ (Liu et al., 2005; Zhu et al., 2009). The diesel generator OC-toEC ratio of 12.7 is in the range previously observed for a diesel generator running on high-sulfur diesel at a relatively low load $(0-25 \mathrm{~kW})$ (Liu et al., 2005), although neither sulfur dioxide (Stockwell et al. 2016) nor sulfate were detected in these emissions. For the petrol generator, EC was not detected, and the measured OC mass (after correction for gas adsorption to the filter) was $118 \%$ of $\mathrm{PM}_{2.5}$ mass, which implies that $\mathrm{OC}$ is the dominant chemical component but indicates that positive artifacts remain despite the correction. In both diesel and petrol generators, OC was mostly insoluble in water $(>73 \%)$, consistent with fresh combustion emissions and fuel and oil evaporation.

Organic species quantified by GC-MS accounted for $12 \%$ of the OC emitted from the diesel generator, inclusive of $n$-alkanes $(11 \%)$, PAH $(0.96 \%)$, and hopanes and steranes $(0.13 \%)$. The $n$-alkanes with $22-23$ carbons contributed the most to OC in diesel generator PM, compared to $n$-alkanes with 13-17 carbons dominating in diesel fuel (Liang et al., 2005). The observed species reflect both combustion (i.e., tailpipe emissions) and engine oil evaporation (Schauer et al., 1999). For the petrol generator, only $3.8 \%$ of OC was attributed to organic species, primarily $n$-alkanes $(0.6 \%)$. Meanwhile, EFs of metals were very similar between the two generator types, indicating that their emissions were independent of fuel type and probably were due to background $\mathrm{PM}$ and/or abrasion. 


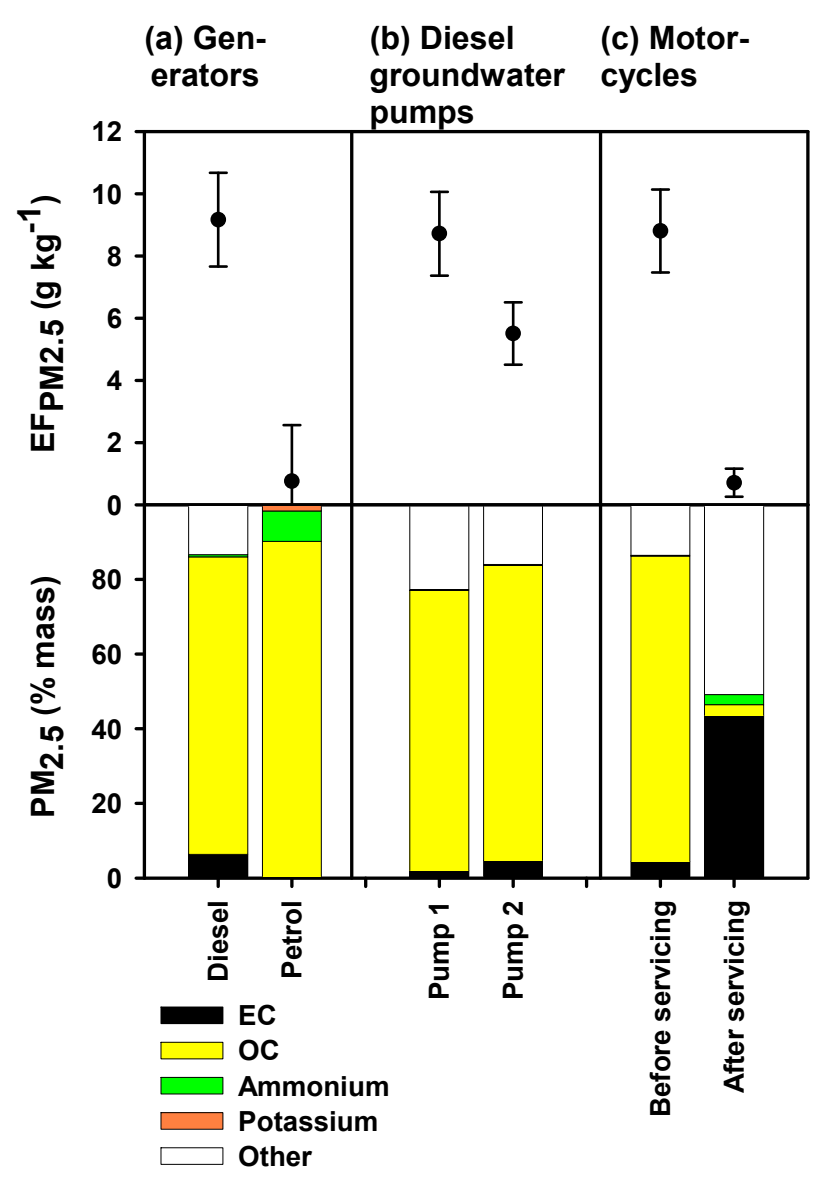

Figure 3. $\mathrm{EF}_{\mathrm{PM}_{2.5}}$ and $\mathrm{PM}_{2.5}$ composition (as percent by mass) for generators (a), diesel groundwater pumps (b), and motorcycles before and after servicing (c). Error bars correspond to analytical uncertainties.

\subsection{Groundwater pumps}

Filter samples from groundwater pumps were collected after the pump had been turned on and reached continuous operating conditions. Thus, the reported EF do not include the initial start-up phase during which the pump was visually observed to emit puffs of black smoke (Stockwell et al., 2016). $\mathrm{EF}_{\mathrm{PM}_{25}}$ for the groundwater pumps was $8.7 \pm 0.7 \mathrm{~g} \mathrm{~kg}^{-1}$ for pump 1 (4.6 kVA model) and $5.5 \pm 0.5 \mathrm{~g} \mathrm{~kg}^{-1}$ for pump 2 (5 kVA model) (Fig. 3b; Table S3). The higher $\mathrm{EF}_{\mathrm{PM}_{2.5}}$ of pump 1 is likely related to its age (approximately 3 years) and lower MCE (0.986) compared to pump 2 that was newer (less than 3 months of use) and had a higher MCE (0.996), since combustion at lower efficiency generates more PM per mass fuel burned. The magnitude of PM emissions from diesel groundwater pumps was similar to the diesel generator in this study (Sect. 3.4) and the EPA emission factor (AP 42) of $6.0 \mathrm{~g} \mathrm{~kg}^{-1}$ (EPA, 1996).

Chemical measurements indicated that the $\mathrm{PM}_{2.5}$ was largely carbonaceous in nature (Table 1). Filter-based mea- surements indicated that the average contributions to PM mass for OC and EC were 77 and $3.4 \%$, respectively, and that $\mathrm{OC}$ was primarily water insoluble $(\geq 88 \%)$. Further discussion on the light-absorbing carbon fraction of diesel pump emissions and a comparison of measurement methods is provided elsewhere (Goetz et al., 2018a). The carbon fraction of the organic species measured by GC-MS accounted for an average of $3.2 \%$ of the OC emitted from the diesel groundwater pumps. $n$-Alkanes contributed the most to the speciated OC mass at $2.4 \%$, with maximum contributions from those with 22-23 carbons, similar to the diesel generator. Engine oil evaporation was reflected by the presence of hopanes $(0.11 \%)$ and combustion indicated by PAHs $(0.4 \%)$. On a species level, the two groundwater pumps had different PAH profiles, with pump 2 emitting PAH primarily in the lower molecular weight range (with maxima for phenanthrene and fluoranthene) and pump 1 emitting PAH with higher molecular weights (with a maximum emission of benzo(ghi)fluoranthene) like the diesel generator (Sect. 3.4). Metals EFs were similar across both groundwater pumps and more generally were consistent with EFs from gasoline and diesel generators. Accordingly, they did not provide a unique metal signature allowing for distinction between generators and groundwater pumps.

\subsection{Motorcycles - before and after servicing}

Emissions from five motorcycles were evaluated while idling before and after servicing, which involved an oil change, cleaning air filters and spark plugs, and adjusting the carburetor. Because of the limited scope of the motorcycle emissions testing, both in terms of drive cycle and number of samples, the following data are neither representative of the diverse Kathmandu vehicle fleet nor their integrated emissions. Instead, we focus on the effect of servicing on emissions under idling conditions. $\mathrm{EF}_{\mathrm{PM}_{2.5}}$ was $8.81 \pm 1.33 \mathrm{~g} \mathrm{~kg}^{-1}$ before servicing and dropped considerably to $0.71 \pm 0.45 \mathrm{~g} \mathrm{~kg}^{-1}$ after servicing (Fig. 3c). OC, the major chemical component of emissions before servicing, dropped from 7.21 to $0.02 \mathrm{~g} \mathrm{~kg}^{-1}$ after servicing. Simultaneous decreases in hopanes $\left(25-1 \mathrm{mg} \mathrm{kg}^{-1}\right)$, steranes $(5.4$ $0.25 \mathrm{mg} \mathrm{kg}^{-1}$ ), and $n$-alkanes $\left(86.7-8.1 \mathrm{mg} \mathrm{kg}^{-1}\right.$ ) indicate that the reductions in $\mathrm{OC}$ are largely due to decreasing emissions of motor oil. Prior studies of vehicle emissions indicate that motor oil emissions originate in the crankcase (Zielinska et al., 2008), suggesting that the engine service reduces the crankcase emissions, perhaps by removing old oil and cleaning the filters. Meanwhile, other emissions categories were largely unchanged before and after servicing, including the measured PAH species (11.2 and $6.8 \mathrm{mg} \mathrm{kg}^{-1}$ ), EC ( 0.39 and $\left.0.31 \mathrm{~g} \mathrm{~kg}^{-1}\right)$, and metals (Table S3). Consequently, the source profiles for motorcycles before and after servicing are significantly different from one another, particularly with respect to their OC:EC, PAH:OC, and metal: $\mathrm{PM}$ ratios. Similar to gasoline-powered vehicles recently serviced, 


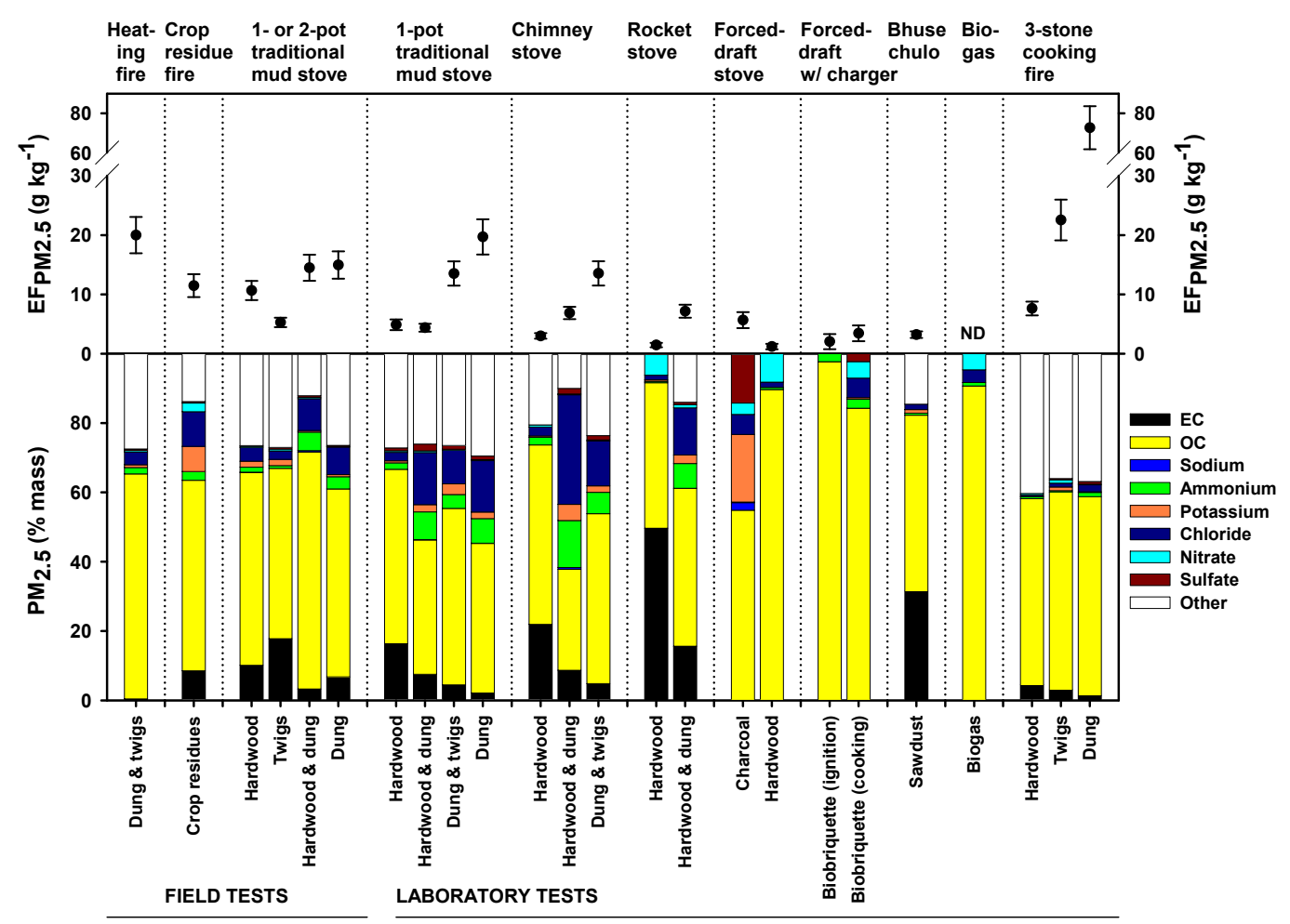

Figure 4. $\mathrm{EF}_{\mathrm{PM}_{25}}$ and $\mathrm{PM}_{2.5}$ composition (as percent by mass) for various types of biomass burning, including open burning (heating and crop residue fires), cooking stoves, and three-stone fires. Within a stove type, fuels are positioned with increasing dung content, revealing that burning or co-burning of dung yielded higher $\mathrm{PM}_{2.5}$ emissions. Error bars correspond to analytical uncertainties.

well-functioning motorcycles have a different emissions profile than motorcycles lacking service (Lough et al., 2007).

Prior studies of motorcycles report condition-based EFs (as $\mathrm{g} \mathrm{km}^{-1}$ or $\mathrm{g} \mathrm{start}^{-1}$ ), which demonstrate that emissions and fuel consumption change under different speeds and conditions (Oanh et al., 2012). Consequently, driving conditionbased EF cannot be directly compared to fuel-based emission factors (in units of $\mathrm{g} \mathrm{kg}^{-1}$ ) from idling vehicles. Instead, we compare the ratios of $\mathrm{EF}_{\mathrm{PM}_{2.5}}$ to $\mathrm{EF}_{\mathrm{CO}}$ determined herein to those from prior studies of vehicles under start-up, which is more comparable than $\mathrm{EF}$ under driving conditions (i.e., highway or street driving). The ratio of $\mathrm{PM}_{2.5}: \mathrm{CO}$ (wt / wt) was $11.4 \%$ o before servicing and $0.89 \%$ after servicing. The before-servicing value is quite similar to the 12.7 and $10.4 \%$ o reported for motorcycle start-up by Oanh et al. (2012) for Hanoi and by Shrestha et al. (2013) for Kathmandu, respectively, both using an adjusted international vehicle emissions (IVEs) EF. In contrast, the post-servicing value observed in this study is remarkably low, due to servicing significantly reducing emissions of PM but slightly increasing CO (Stockwell et al., 2016).

Changes to motorcycle EF before and after servicing indicate that major reductions in $\mathrm{PM}_{2.5}, \mathrm{OC}$, and motor oil constituents in particular may be achieved by vehicle servicing. In addition, Stockwell et al. (2016) demonstrated that ser- vicing also has the benefit of reducing gaseous emissions of $\mathrm{NO}_{X}$ and non-methane hydrocarbons, amid slight increases in $\mathrm{CO}$ emissions. Follow-up studies of individual motorcycles in Nepal (rather than the combined emissions from five motorcycles presented herein) have indicated that the major PM reductions we reported here were probably due to the servicing of one high-emitting motorcycle (ICIMOD, unpublished data), suggesting that efforts to reduce $\mathrm{PM}_{2.5}$ emissions from motorcycles should initially focus on high emitters. This approach is supported by the work of Zhang et al. (1995) on CO emissions from vehicles in Kathmandu and elsewhere that have demonstrated that high-emitting vehicles account for a large fraction of fleet emissions and that highemitting vehicles generally lack maintenance and repair.

\subsection{Emissions from the combustion of biofuels in cooking stoves and three-stone cooking fires}

$\mathrm{EF}_{\mathrm{PM}_{2.5}}$ for the combustion of various biofuels in cooking stoves and three-stone cooking fires are shown in Fig. 4, while MCEs are provided in tabular format in Table S3. Our discussion emphasizes the four field tests conducted in traditional mud stoves, which are considered to be the best representation of real-world cooking emissions from traditional mud stoves in this study. $\mathrm{EF}_{\mathrm{PM}_{2.5}}$ determined from these field tests were $10.7 \pm 1.6 \mathrm{~g} \mathrm{~kg}^{-1}$ for hardwood, $5.3 \pm 0.8 \mathrm{~g} \mathrm{~kg}^{-1}$ 
for twigs, $14.5 \pm 2.2 \mathrm{~g} \mathrm{~kg}^{-1}$ for dung (all in a one-pot stove) and $15.0 \pm 2.3 \mathrm{~g} \mathrm{~kg}^{-1}$ for a mixture of dung and hardwood (in a two-pot stove). The magnitude of these values was up to 3 times higher than the EF reported for traditional mud stoves by Venkataraman and Rao (2001) that ranged from 2.8 to $4.8 \mathrm{~g} \mathrm{~kg}^{-1}$ for wood, biofuel briquettes, and dung that were diluted before sampling. The observed $\mathrm{EF}_{\mathrm{PM}_{2.5}}$ for traditional mud stoves are greater than values compiled by Akagi et al. (2011) for $\mathrm{EF}_{\mathrm{PM}_{2.5}}$ from open cooking that averaged $6.73 \pm 1.61 \mathrm{~g} \mathrm{~kg}^{-1}$ but were lower than the particulate carbon emissions reported by Keene et al. (2006) for dung burning $\left(22.9 \mathrm{~g} \mathrm{~kg}^{-1}\right)$. In addition to fuel type, variability in $\mathrm{EF}_{\mathrm{PM}_{2.5}}$ in cooking stove emissions has been attributed to the extent of flaming or smoldering combustion, with peak PM emissions occurring during the latter stage (Arora et al., 2014); dilution prior to PM collection (as discussed at the onset of Sect. 3); rate of fuel consumption (Venkataraman et al., 2005); air flow through the stove (e.g., natural or forced draft); and pot size and material (Gupta et al., 1998; Kar et al., 2012). The fact that field tests gave average $\mathrm{EF}_{\mathrm{PM}_{2.5}}$ in the upper range of previously reported values is significant with respect to estimations of regional emissions from this stove type.

The comparison of emissions from one- or two-pot traditional mud stoves studied in the laboratory to those in the field showed that MCE was lower in the field samples (averaging 0.925) than in the lab samples (averaging 0.958) at a statistically significant level $(p=0.01)$. This suggests that field fires normally burn with a lower degree of combustion efficiency than in controlled studies. The decrease in combustion efficiency in the field compared to the laboratory has been previously reported for cooking stoves, particularly in the case of open fires, and is attributed to operator skill (Johnson et al., 2008; Jetter and Kariher, 2009; Roden et al., 2009). EFs for $\mathrm{PM}_{2.5}$, OC, and EC, however, were not significantly different across the field and laboratory samples $(p>0.05)$, although significant increases in PM emissions for stoves in the field compared to the laboratory have been demonstrated in larger cooking stove studies (Johnson et al., 2008; Roden et al., 2009). In a comparison of the laboratory $\mathrm{EF}_{\mathrm{PM}}$ to the literature, the reported values are elevated with respect to some previously reported values (Akagi et al., 2011; Venkataraman and Rao, 2001) but lower than other cases (Keene et al., 2006). MCE was strongly correlated with $\mathrm{PM}_{2.5}$ for the biofuel laboratory tests $(r=-0.959 ; n=16$; Fig. 5), excluding charcoal and biogas fuels. When including the three-stone fire burning dung (with an exceptionally high $\mathrm{EF}_{\mathrm{PM}_{2.5}}$ of $72.7 \mathrm{~g} \mathrm{~kg}^{-1}$ and MCE of 0.863 ), this correlation increased slightly $(r=-0.979)$. In contrast, EFs for PM were only weakly correlated with MCE in the four fieldbased tests $(r=-0.394)$; this makes it difficult to determine how much of the difference between lab and field is due to differences in combustion state (smoldering vs. flaming). For this dataset, simply estimating $\mathrm{EF}_{\mathrm{PM}_{2.5}}$ from MCE using re-

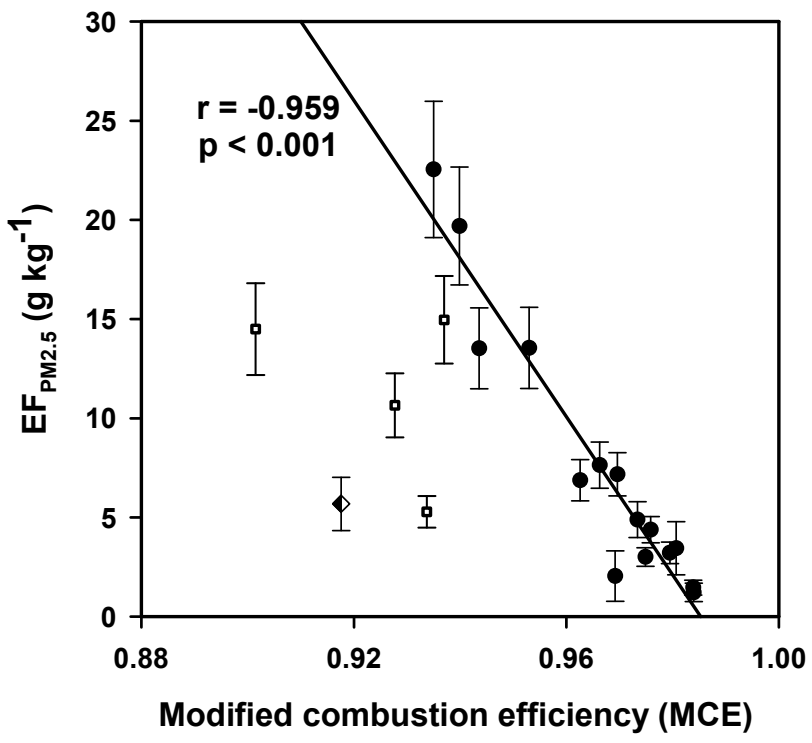

- Biofuels in laboratory
- $\quad$ Biofuels in field
Charcoal in laboratory

Figure 5. A scatterplot of $\mathrm{MCE}$ vs. $\mathrm{EF}_{\mathrm{PM}_{2.5}}$, with the regression line applied only to the biofuel samples in the laboratory combustion tests. Excluded from this regression were charcoal burning, biogas, and the very high $\mathrm{EF}_{\mathrm{PM}_{2.5}}$ for the three-stone fire fueled with dung (see Sect. 3.7). The field tests consistently fall below the regression line, indicating that biomass burning measured in the field is generally lower in MCE compared to the laboratory measurements.

lationships developed in the laboratory would overestimate $\mathrm{EF}_{\mathrm{PM}_{2.5}}$ in the field.

The use of dung, or a mixture of dung and wood, consistently gave higher $\mathrm{EF}_{\mathrm{PM}_{2.5}}$ than burning wood alone for both field-based and laboratory studies (Fig. 4). The higher $\mathrm{EF}_{\mathrm{PM}}$ from dung compared to wood has been observed previously for fuel-based and energy-based EFs (Venkataraman and Rao, 2001; Sheesley et al., 2003; Keene et al., 2006; Oanh et al., 1999; Saud et al., 2013). The induced-draft stove when burning charcoal emitted less PM than a mixture of hardwood and dung (Fig. 4), consistent with prior studies that demonstrated that charcoal leads to relatively low PM emissions (Kshirsagar and Kalamkar, 2014). Likewise, biobriquettes have been shown to have lower EFPM compared to wood and dung (Oanh et al., 1999; Sheesley et al., 2003). Among the cooking fuels we measured, biogas had the lowest $\mathrm{EF}_{\mathrm{PM}_{2.5}}$ overall, but it is not widely used. Together, results from this and prior studies demonstrate that on a per massof-fuel basis, dung is a high PM emitter, followed by wood, biobriquettes, and charcoal, with biogas providing the lowest PM emissions. 
The control of fuel burned in the laboratory allows for comparison across different stove designs and threestone cooking fires. In the case of hardwood, the highest $\mathrm{PM}_{2.5}$ emissions were observed for the three-stone cooking fire $\left(7.6 \mathrm{~g} \mathrm{~kg}^{-1}\right)$, followed by the one-pot traditional mud stove $\left(4.9 \pm 0.9 \mathrm{~g} \mathrm{~kg}^{-1}\right)$, chimney stove $\left(3.0 \pm 0.5 \mathrm{~g} \mathrm{~kg}^{-1}\right)$, rocket stove $\left(1.47 \pm 0.4 \mathrm{~g} \mathrm{~kg}^{-1}\right)$, and the forced-draft stove $\left(1.2 \pm 0.5 \mathrm{~g} \mathrm{~kg}^{-1}\right)$. As the $\mathrm{EF}_{\mathrm{PM}_{2.5}}$ for hardwood decreases, the MCE increases (Table S2) consistent with smoldering conditions emitting more $\mathrm{PM}_{2.5}$. When dung was used as fuel, the three-stone cooking fire again generated the highest $\mathrm{EF}_{\mathrm{PM}_{2.5}}\left(73 \pm 11 \mathrm{~g} \mathrm{~kg}^{-1}\right)$ followed by the one-pot traditional mud stove $\left(20 \pm 3 \mathrm{~g} \mathrm{~kg}^{-1}\right)$. More generally, and considering the breadth of the fuels studied, the comparisons of different cooking stoves and cooking fires revealed the highest PM emissions from three-stone cooking fires $\left(7.6-73 \mathrm{~g} \mathrm{~kg}^{-1}\right)$, followed by traditional mud stoves $(5.3-$ $\left.19.7 \mathrm{~g} \mathrm{~kg}^{-1}\right)$, mud stoves with a chimney for exhaust (3.0$\left.6.8 \mathrm{~g} \mathrm{~kg}^{-1}\right)$, and then rocket $\left(1.5-7.2 \mathrm{~g} \mathrm{~kg}^{-1}\right)$, induced-draft stoves (1.2-5.7 $\left.\mathrm{g} \mathrm{kg}^{-1}\right)$, and bhuse chulo $\left(3.2 \mathrm{~g} \mathrm{~kg}^{-1}\right)$, while biogas had no detectable PM emissions. The observed trends across stove types are consistent with prior studies of cooking stoves. Here and in prior studies, biogas holds advantages over traditional cooking stoves in terms of the reduced global warming potential of emissions and provides a viable and cleaner-emissions alterative to the direct combustion of dung as fuel (Smith et al., 2000). Several prior studies have also documented that vented, natural-draft, and forced-draft stoves provide lower PM emissions (Smith et al., 2000; Jetter and Kariher, 2009; Jetter et al., 2012).

The PM emitted from biofuel burning was primarily carbonaceous matter (Fig. 4; Table 3). For the four field tests of traditional mud stoves, $\mathrm{PM}_{2.5}$ mass was comprised of 49-68\% OC and 3.3-18\% EC (Table S2). On average, $34 \pm 3 \%$ of OC was water soluble, with the majority being water insoluble. Ratios of OC: EC ranged from 2.8 to 21 , with the greatest values corresponding to the use of dung as fuel. This range of $\mathrm{OC}$ : EC values and trend with maximum OC: EC occurring for dung cake are consistent with prior studies of similar fuel types in the IGPs (Saud et al., 2013; Deka and Hoque, 2015). Major inorganic ions contributing to $\mathrm{PM}_{2.5}$ mass include potassium $(0.5-1.8 \%$ ), ammonium (0.8-5.3\%), and chloride (2.4-9.2\%), with minor contributions $(<0.6 \%)$ from sodium, fluoride, nitrate, and sulfate. The largest mass fractions of ammonium and chloride in $\mathrm{PM}_{2.5}$ were observed for fuel blends that included dung. Chlorides in $\mathrm{PM}_{2.5}$ emitted from biofuel burning are primarily in the form of water-soluble salts (Keene et al., 2006; Sheesley et al., 2003). In emissions involving dung, ammonium is the dominant counter ion to chloride, while both ammonium and potassium contribute appreciably as counter ions to chloride in $\mathrm{PM}_{2.5}$ emissions from wood. This difference in chloride salt composition is derived from dung having a significantly higher mass fraction of nitrogen compared to grasses and wood fuels (Keene et al., 2006). In ad-

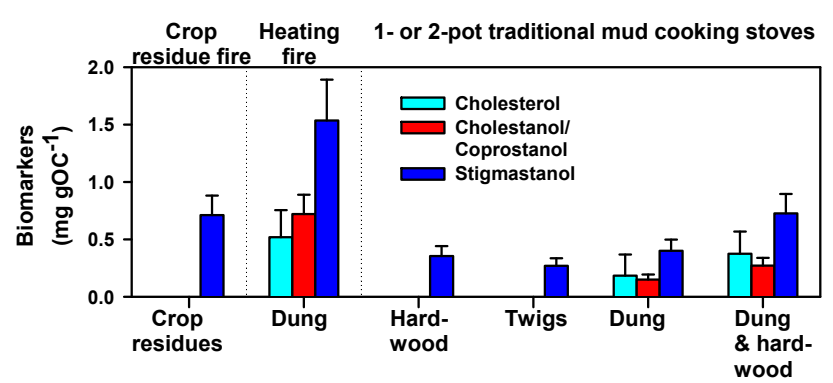

Figure 6. Emission ratios of select organic species in field tests, normalized to OC $\left(\mathrm{mg} \mathrm{g} \mathrm{OC}^{-1}\right)$ for open burning (crop residue and heating fires) and one- to two-pot traditional mud cooking stoves. Normalization to $\mathrm{OC}$ accounts for the large changes in $\mathrm{EF}_{\mathrm{OC}} \mathrm{ob}-$ served across different combustion scenarios and demonstrates consistency in the molecular marker-to-OC ratios for common fuels. Cholesterol, cholestanol, and coprostanol are observed only when dung is burned.

dition, dung burning had higher mass contributions for chloride, while wood, twig, and agricultural residue burning had relatively more potassium. Charcoal burning PM was particularly enriched in potassium ( $28 \pm 7 \%$ by mass) and sulfate ( $21 \pm 6 \%$ by mass), in contrast to the other studied fuels that had lower mass fractions of these ions. For 19 of 24 biofuels, the sum of the measured PM components was less than the measured $\mathrm{PM}_{2.5}$ mass, and non-carbon elements associated with organic matter (i.e., hydrogen, oxygen, nitrogen) are expected to make up the majority of this difference.

In the case of hardwood burning in the rocket stove, hardwood burning in the forced-draft stove, and biobriquettes in the forced-draft stove with an electrical charger under ignition and cooking conditions, the measured OC exceeded the measured $\mathrm{PM}_{2.5}$ mass by a factor of 3 . All of these sources had relatively low $\mathrm{PM}_{2.5}$ emissions in comparison to other stove types. The results suggest that the measured $\mathrm{OC}$ was overestimated, despite the correction for gas adsorption. Because organic gas adsorption affects QFF but not Teflon filters, the $\mathrm{EF}_{\mathrm{PM}_{2.5}}$ measurement for these stove types is considered valid.

Organic molecular markers provide additional means of chemically distinguishing between $\mathrm{PM}_{2.5}$ emissions from different fuel types. Sheesley et al. (2003) found that cow dung burning uniquely emits three stanols $-5 \beta$-stigmastanol, coprostanol, and cholestanol - that are characteristic of anaerobic microbial reduction that occurs during digestion in higher animals. In this study, $5 \beta$-stigmastanol, was detected in emissions from the combustion of hardwood as well as twigs (Fig. 6) indicating that either this molecule is not unique to dung burning or the GC-MS measurement method used in this study was unable to distinguish between $5 \alpha$ - and $5 \beta$-stigmastanol, of which the former has been reported in woodsmoke (Fine et al., 2001). Consequently, we do not consider $5 \beta$-stigmastanol to be a unique 
Table 4. Summary of emissions data for biofuel combustion sources with respect to organic species normalized to organic carbon mass $\left(\mathrm{mg} \mathrm{g} \mathrm{OC}^{-1}\right)$. Tricyclic terpanes were not detected. Errors are shown in parentheses; a description of their calculation is provided in Sect. 3. Missing values are below the method detection limits, which are provided sample by sample in Table S1.

\begin{tabular}{|c|c|c|c|c|c|c|c|c|}
\hline \multirow{2}{*}{$\begin{array}{l}\begin{array}{l}\text { Combustion } \\
\text { source }\end{array} \\
\text { Fuel }\end{array}$} & \multicolumn{2}{|c|}{$\begin{array}{l}\text { Traditional mud } \\
\text { cooking stove }\end{array}$} & \multicolumn{2}{|c|}{$\begin{array}{l}\text { Traditional mud } \\
\text { cooking stove }\end{array}$} & \multicolumn{2}{|c|}{ Agricultural fire } & \multicolumn{2}{|c|}{ Open burning } \\
\hline & \multicolumn{2}{|c|}{ Wood } & \multicolumn{2}{|c|}{ Wood, dung } & \multicolumn{2}{|c|}{ Crop residues* } & \multicolumn{2}{|c|}{ Dung, twigs } \\
\hline \multicolumn{9}{|c|}{ Polycyclic aromatic hydrocarbons } \\
\hline Phenanthrene & 0.14 & $(0.11)$ & 0.18 & $(0.15)$ & 0.03 & $(0.01)$ & 0.04 & $(0.01)$ \\
\hline Anthracene & 0.06 & $(0.05)$ & 0.11 & $(0.12)$ & 0.017 & $(0.004)$ & & \\
\hline Fluoranthene & 0.94 & $(0.03)$ & 0.58 & $(0.19)$ & 0.24 & $(0.06)$ & 0.16 & $(0.04)$ \\
\hline Pyrene & 1.16 & $(0.07)$ & 0.55 & $(0.32)$ & 0.26 & $(0.06)$ & 0.19 & $(0.04)$ \\
\hline Methylfluoranthene & 0.39 & $(0.09)$ & 0.20 & $(0.03)$ & 0.11 & $(0.03)$ & 0.08 & $(0.02)$ \\
\hline 9-Methylanthracene & 0.03 & $(0.01)$ & 0.03 & $(0.01)$ & 0.09 & $(0.02)$ & 0.03 & $(0.01)$ \\
\hline Benzo(ghi)fluoranthene & 1.17 & $(0.59)$ & 0.50 & $(0.05)$ & 0.17 & $(0.04)$ & 0.10 & $(0.02)$ \\
\hline Cyclopenta(cd)pyrene & 1.54 & $(0.86)$ & 0.56 & $(0.25)$ & 0.04 & $(0.01)$ & 0.06 & $(0.01)$ \\
\hline Benz(a)anthracene & 1.02 & $(0.50)$ & 0.48 & $(0.10)$ & 0.13 & $(0.03)$ & 0.14 & $(0.03)$ \\
\hline Chrysene & 0.76 & $(0.38)$ & 0.30 & $(0.003)$ & 0.11 & $(0.03)$ & 0.13 & $(0.03)$ \\
\hline 1-Methylchrysene & 0.12 & $(0.05)$ & 0.06 & $(0.01)$ & 0.03 & $(0.01)$ & 0.03 & $(0.01)$ \\
\hline Retene & & & 0.03 & $(0.01)$ & 0.04 & $(0.01)$ & & \\
\hline Benzo(b)fluoranthene & 0.86 & $(0.25)$ & 0.39 & $(0.11)$ & 0.13 & $(0.03)$ & 0.10 & $(0.02)$ \\
\hline Benzo(k)fluoranthene & 0.35 & $(0.27)$ & 0.17 & $(0.02)$ & 0.05 & $(0.01)$ & 0.04 & $(0.01)$ \\
\hline Benzo(j)fluoranthene & 0.39 & $(0.21)$ & 0.19 & $(0.11)$ & 0.03 & $(0.01)$ & 0.12 & $(0.03)$ \\
\hline Benzo(e)pyrene & 0.39 & $(0.18)$ & 0.19 & $(0.05)$ & 0.09 & $(0.02)$ & 0.07 & $(0.02)$ \\
\hline Benzo(a)pyrene & 0.85 & $(0.48)$ & 0.33 & $(0.07)$ & 0.10 & $(0.02)$ & 0.07 & $(0.02)$ \\
\hline Perylene & 0.18 & $(0.03)$ & 0.08 & $(0.06)$ & 0.002 & $(0.004)$ & 0.003 & $(0.003)$ \\
\hline Indeno(1,2,3-cd)pyrene & 0.52 & $(0.39)$ & 0.20 & $(0.09)$ & 0.07 & $(0.02)$ & 0.04 & $(0.01)$ \\
\hline Benzo(ghi)perylene & 0.49 & $(0.08)$ & 0.30 & $(0.25)$ & 0.06 & $(0.02)$ & 0.03 & $(0.01)$ \\
\hline Dibenz(ah)anthracene & 0.10 & $(0.03)$ & 0.06 & $(0.03)$ & & & 0.02 & $(0.01)$ \\
\hline Picene & 0.25 & $(0.06)$ & 0.13 & $(0.10)$ & & & 0.01 & $(0.004)$ \\
\hline \multicolumn{9}{|l|}{ Triphenylbenzene } \\
\hline \multicolumn{9}{|l|}{ Alkanes } \\
\hline Pristane & 0.03 & $(0.16)$ & 0.15 & $(0.03)$ & 0.18 & $(0.27)$ & & \\
\hline Norpristane & 0.01 & $(0.06)$ & 0.05 & $(0.01)$ & 0.06 & $(0.09)$ & & \\
\hline Phytane & & & 0.02 & $(0.02)$ & 0.02 & $(0.14)$ & & \\
\hline Squalane & & & 0.16 & $(0.09)$ & 0.10 & $(0.28)$ & 0.43 & $(0.22)$ \\
\hline Octadecane & & & 0.05 & $(0.01)$ & 0.02 & $(0.08)$ & & \\
\hline Nonadecane & & & 0.16 & $(0.01)$ & 0.22 & $(0.26)$ & & \\
\hline Eicosane & 0.06 & $(0.07)$ & 0.39 & $(0.14)$ & 0.41 & $(0.34)$ & 0.10 & $(0.21)$ \\
\hline Heneicosane & 0.13 & $(0.04)$ & 0.43 & $(0.04)$ & 0.36 & $(0.10)$ & 0.27 & $(0.07)$ \\
\hline Docosane & 0.06 & $(0.58)$ & 0.34 & $(0.19)$ & 0.20 & $(0.86)$ & 0.43 & $(0.60)$ \\
\hline Tricosane & 0.10 & $(0.02)$ & 0.61 & $(0.13)$ & 0.73 & $(0.45)$ & 1.45 & $(0.47)$ \\
\hline Tetracosane & & & 0.47 & $(0.17)$ & 0.20 & $(0.76)$ & 1.66 & $(0.68)$ \\
\hline Pentacosane & & & 0.50 & $(0.23)$ & 0.15 & $(1.10)$ & 1.29 & $(0.84)$ \\
\hline Hexacosane & & & 0.21 & $(0.21)$ & & & 0.92 & $(0.89)$ \\
\hline Heptacosane & & & 0.78 & $(0.45)$ & 0.20 & $(1.32)$ & 2.07 & $(1.08)$ \\
\hline Octacosane & 0.12 & $(0.57)$ & 0.42 & $(0.16)$ & & & 1.95 & $(0.79)$ \\
\hline Nonacosane & 0.26 & $(0.59)$ & 1.79 & $(0.40)$ & 2.00 & $(1.05)$ & 4.47 & $(1.27)$ \\
\hline Triacontane & 0.11 & $(0.06)$ & 1.01 & $(0.25)$ & & & 2.83 & $(0.89)$ \\
\hline Hentriacontane & 0.19 & $(0.16)$ & 2.06 & $(0.90)$ & 0.15 & $(0.59)$ & 6.71 & (1.67) \\
\hline Dotriacontane & 0.11 & $(0.25)$ & 0.56 & $(0.23)$ & & & 2.53 & $(0.69)$ \\
\hline Tritriacontane & 0.17 & $(0.14)$ & 1.07 & $(0.35)$ & 0.11 & $(0.36)$ & 4.94 & $(1.21)$ \\
\hline Tetratriacontane & 0.31 & $(0.15)$ & 0.42 & $(0.16)$ & 0.22 & $(0.19)$ & 1.31 & $(0.34)$ \\
\hline Pentatriacontane & & & 0.26 & $(0.08)$ & & & 1.06 & $(0.28)$ \\
\hline
\end{tabular}

* Rice, wheat, mustard, lentil, and grasses. 
Table 4. Continued.

\begin{tabular}{|c|c|c|c|c|c|c|c|c|}
\hline $\begin{array}{l}\text { Combustion } \\
\text { source }\end{array}$ & \multicolumn{2}{|c|}{$\begin{array}{l}\text { Traditional mud } \\
\text { cooking stove }\end{array}$} & \multicolumn{2}{|c|}{$\begin{array}{l}\text { Traditional mud } \\
\text { cooking stove }\end{array}$} & \multicolumn{2}{|c|}{ Agricultural fire } & \multicolumn{2}{|c|}{ Open burning } \\
\hline Fuel & \multicolumn{2}{|c|}{ Wood } & \multicolumn{2}{|c|}{ Wood, dung } & \multicolumn{2}{|c|}{ Crop residues* } & \multicolumn{2}{|c|}{ Dung, twigs } \\
\hline Levoglucosan & 115.1 & $(57.2)$ & 48.2 & $(14.2)$ & 291 & $(67)$ & 33.7 & (7.8) \\
\hline \multicolumn{9}{|l|}{ Sterols and stanols } \\
\hline Cholesterol & & & 0.28 & $(0.14)$ & & & 0.52 & $(0.24)$ \\
\hline Stigmasterol & 0.66 & $(0.14)$ & 0.69 & $(0.32)$ & 3.68 & $(0.86)$ & 0.82 & $(0.20)$ \\
\hline b-Sitosterol & 3.51 & $(0.21)$ & 1.06 & $(0.33)$ & 6.31 & $(1.55)$ & 1.70 & $(0.47)$ \\
\hline Campesterol & 1.48 & $(0.36)$ & 0.82 & $(0.36)$ & 3.04 & $(0.70)$ & 1.02 & $(0.24)$ \\
\hline Cholestanol and coprostanol & & & 0.21 & $(0.09)$ & & & 0.72 & $(0.17)$ \\
\hline Stigmastanol & 0.31 & $(0.06)$ & 0.56 & $(0.23)$ & & & 1.54 & $(0.36)$ \\
\hline
\end{tabular}

* Rice, wheat, mustard, lentil, and grasses.

marker for dung burning. Coprostanol and cholestanol are diastereomers that co-eluted from the GC column and had identical mass spectra, so they were quantified together. Coprostanol and/or cholestanol were uniquely detected in $\mathrm{PM}_{2.5}$ emitted from dung burning (Fig. 6, Table 4), further supporting that these species are unique molecular markers of this source. As a mass fraction of OC, coprostanol and cholestanol emissions from traditional mud stoves ranged from 0.15 to $0.27 \mathrm{mg} \mathrm{g} \mathrm{OC}^{-1}$; these values are 1 order of magnitude lower than those reported by Stone et al. (2010) for cow dung cake burning in a traditional mud stove and are nearly 2 orders of magnitude lower than those reported by Sheesley et al. (2003) for a catalyst-equipped wood stove. Meanwhile, levoglucosan - a biomass burning marker (Simoneit et al., 1999) - was emitted at comparable levels from all three studies, suggesting that stanol emissions are particularly sensitive to dung burning conditions in comparison to levoglucosan. Due to their specificity, coprostanol and cholestanol are recommended for use as molecular markers of dung combustion; however, source apportionment will be sensitive to the dung burning profile used, due to the high variability in the marker-to-OC ratios, and thus sensitivity testing to the input dung burning profile is recommended.

\subsection{Open burning of biomass: crop residue and heating fires}

One sample was collected from the co-firing of several crop residue fuel types, including rice, wheat, mustard, lentils, and grasses during the pre-monsoon in the Tarai. $\mathrm{EF}_{\mathrm{PM}_{2.5}}$ was $11.5 \pm 2.2 \mathrm{~g} \mathrm{~kg}^{-1}$. The corresponding gas-phase data for this mixed crop residue fire may be found in Stockwell et al. (2016, column B in Table S9 in their Supplement). The majority of PM mass was explained as OC (55\%), EC $(8.6 \%)$, chloride $(10 \%)$, potassium $(7.2 \%)$, ammonium $(2.5 \%)$, and nitrate (2.5\%) (Fig. 4). A relatively high mass fraction of chloride was observed and, combined with the non-detection of $\mathrm{HCl}$ in the gas phase (Stockwell et al., 2016), this indicates that particle-phase chloride was the major form. In addition, higher concentrations of levoglucosan and other biomarkers were present in emissions from this source, although no unique marker species were identified among those reported in Table 3. These data expand both the number and chemical detail of prior emissions measurements of agricultural fires in the IGPs (Rajput et al., 2014a, b; Singh et al., 2014).

Open burning was also examined in the form of a heating fire, in which dung and twigs were burned outdoors in a pile as a means of generating heat. $\mathrm{EF}_{\mathrm{PM}_{2.5}}$ was $20.0 \pm 1.4 \mathrm{~g} \mathrm{~kg}^{-1}$. Two factors are likely to contribute to this relatively high $\mathrm{EF}_{\mathrm{PM}_{2.5}}$ : the inclusion of dung as fuel, which generates more PM than wood fuels (Sect. 3.7), and the low MCE value $(0.861)$, which corresponds to relatively more smoldering. OC comprised $64.9 \%$ of $\mathrm{PM}_{2.5}$, while EC contributed $0.40 \%$; the high OC: $\mathrm{EC}$ ratio $(\sim 150)$ also indicates smoldering combustion conditions. Additionally, this fire contained dung burning tracers coprostanol and cholestanol, lower amounts of levoglucosan relative to wood burning (but values on par with dung-fueled cooking), and a relatively high ratio of ammonium to potassium. This source profile provides insight into open co-burning of dung and fuelwood under smoldering conditions in the Tarai.

\subsection{Potential applications of emission factors and source profiles}

The fuel-based EFs generated in NAMaSTE (Tables 1-4, and S3) have several potential applications. First, when combined with activity data (i.e., mass consumption of fuels), emissions inventories specific to Nepal and the IGPs may be generated. The use of locally and regionally specific EFs are expected to provide a more accurate representation of sources and are expected to improve air quality and climate models for the region. Alternatively, emissions inventories using 
Table 5. Comparison of brick kiln emissions of $\mathrm{PM}_{2.5}, \mathrm{OC}$, and $\mathrm{BC}$ in this study to prior studies of similar kiln design.

\begin{tabular}{lcrrrrl}
\hline Kiln type (location) & $n$ & MCE & $\begin{array}{r}\mathrm{EF} \mathrm{PM}_{2.5} \\
\left(\mathrm{~g} \mathrm{~kg}^{-1}\right)\end{array}$ & $\begin{array}{r}\mathrm{EF} \mathrm{OC} \\
\left(\mathrm{g} \mathrm{kg}^{-1}\right)\end{array}$ & $\begin{array}{r}\mathrm{EF} \mathrm{BC} \\
\left(\mathrm{g} \mathrm{kg}^{-1}\right)\end{array}$ & Reference \\
\hline Clamp (Nepal) & 3 & 0.950 & $10.7 \pm 1.6$ & 6.74 & 0.02 & This study and Stockwell et al. (2016) \\
Induced-draft zigzag (Nepal) & 3 & 0.994 & $15.1 \pm 3.7$ & 1.0 & 0.11 & This study and Stockwell et al. (2016) \\
Induced-draft zigzag (India) & 3 & 0.987 & $0.6-1.2$ & $0.01-0.7$ & $0.07-0.5$ & Weyant et al. (2014) \\
Batch-style (Mexico) & 2 & 0.968 & $1.2-2.0^{*}$ & $0.07-2.8$ & $0.6-1.5$ & Christian et al. (2010) \\
\hline
\end{tabular}

${ }^{*}$ Estimated from measurements of OC, EC, metals, and ions (but not sulfate).

global average values can be based on more data. Energybased EFs (mass of pollutant per energy output) can be calculated from these EFs (mass of PM per mass of fuel) and fuel energy densities (energy per mass of fuel). Second, detailed chemical profiles may be used in receptor-based source apportionment modeling following the chemical mass balance approach (Schauer et al., 1996; Stone et al., 2010). This model requires that the input source profiles represent sources likely to impact the receptor location. The source profiles presented herein depict in situ emissions from many important and previously under-characterized sources and therefore are considered to be the most representative source profiles for many sources in Nepal and South Asia. When apportioning OC based on organic tracers, highly sourcespecific tracers will be useful in the delineation of regionally important sources (e.g., TPB and Sb from garbage burning, coprostanol and cholestanol for dung burning). Third, when combined with gas-phase emissions data from Stockwell et al. (2016), acute to chronic health risks may be assessed among the major gaseous and particle-phase species emitted. Through these intended applications, these emissions data can contribute to a better understanding of air quality, PM sources, and their impacts on human health.

Source-averaged $\mathrm{EF}_{\mathrm{PM}_{2.5}}$ and composition data provided in Tables 1-4 are intended for use in the abovementioned applications. Notably, the relative errors in $\mathrm{PM}_{2.5}$ and $\mathrm{OC}$ mass have been incorporated into the errors reported for bulk chemical constituents and organic species shown as ratios, respectively. Use of these values should maintain the reported relative errors (in parentheses in Tables 1-4) and should not be propagated to include errors in $\mathrm{EF}_{\mathrm{PM}_{2.5}}$ or $\mathrm{EF}_{\mathrm{OC}}$, as this would be redundant.

\section{Conclusions}

We report $\mathrm{EF}_{\mathrm{PM}_{2.5}}$ for a number of different widespread and under-sampled combustion sources in Nepal, including brick kilns, garbage burning, diesel and gasoline generators, diesel groundwater pumps, traditional and modern cooking stoves, crop residue burning, and open burning of biofuels. These data expand the understanding of combustion emissions in a number of ways. First, we provide the first $\mathrm{EF}_{\mathrm{PM}}$ for diesel groundwater pumps, which are prevalent in South Asia. Sec- ond, we add to the body of literature on PM emissions for brick kilns, garbage burning, generators, cooking stoves, and open biomass fires, in many cases expanding the chemical detail that is known about PM composition. Third, we confirm that molecular and elemental tracers identified in previous studies are applicable to South Asian combustion sources, namely $\mathrm{Sb}$ and TPB for garbage burning and coprostanol and cholestenol for dung burning, which are useful in source identification and apportionment. Fourth, through the study of motorcycle emissions before and after servicing, we demonstrate that significant PM reductions may be achieved by servicing. Fifth, our data suggest that the burning of wet garbage substantially increases PM emissions relative to dry garbage, which warrants further investigation. Finally, NAMaSTE is the first to provide a detailed chemical characterization of in situ combustion emissions from within Nepal, providing locally and regionally specific emissions data. In combination with colocated measurements reported by Stockwell et al. (2016) that include aerosol optical properties (EFs for scattering and absorption, single scattering albedo, and absorption Ångström exponent) and EFs for $\sim 80$ important gases, a chemically and physically thorough analysis of the sampled combustion emissions is provided. Colocated, size-resolved emissions measurements of these sources by AMS will provide further chemical insight into aerosol composition (Goetz et al., 2018a, b).

With a focus on a detailed characterization of understudied source sectors, NAMaSTE does not fully capture the broad diversity of combustion sources in the IGPs and South Asia. This is partly because NAMaSTE was reduced in scope in response to the Gorkha earthquake, resulting in fewer replicates and the numbers of sources studied. Analyses of rapidly changing vehicle fleets, particularly under driving conditions found in the region, are needed to better constrain emissions from this source sector. For other source categories, further field-based studies are needed to better understand source variability and diversity. In particular, the inherent heterogeneity in garbage composition and apparent sensitivity of its emissions to combustion conditions such as moisture content warrants further inquiry. Likewise, moisture affects emissions from biomass, especially in open burning of wood and crop residues. The present and future improvements to understanding emissions in this region 
will provide a more accurate representation of air pollution sources within South Asia and can support updates to emissions inventories, improvements to regional air quality and climate models, and assessments of air quality impacts on health.

Data availability. Emissions and sampling data reported herein are provided in the Supplement for each individual sample.

\section{The Supplement related to this article is available online at https://doi.org/10.5194/acp-18-2259-2018-supplement.}

Competing interests. The authors declare that they have no conflict of interest.

Acknowledgements. This project was funded by the National Science Foundation through the grant entitled "Collaborative Research: Measurements of Selected Combustion Emissions in Nepal and Bhutan Integrated with Source Apportionment and Chemical Transport Modeling for South Asia”. Elizabeth A. Stone and Thilina Jayarathne were supported by NSF grant number AGS 1351616, Robert J. Yokelson and Chelsea E. Stockwell were supported by AGS 1349967, J. Douglas Goetz and Peter F. DeCarlo were supported by AGS 1461458, and Eri Saikawa was supported by AGS 1350021. Robert J. Yokelson was also supported by NASA Earth Science Division Award NNX14AP45G. Prakash V. Bhave, Puppala S. Praveen, Sagar Adhikari, Rasmi Maharjan, and Arnico K. Panday were partially supported by core funds of ICIMOD contributed by the governments of Afghanistan, Australia, Austria, Bangladesh, Bhutan, China, India, Myanmar, Nepal, Norway, Pakistan, Switzerland, and the UK. We thank Sanu Babu Dangol, Shradda Dhungel, Sudip Ghimire, and Mukesh Rai for identifying and arranging access to the field sampling sites; Bijaya Raj Khanal for assisting with the lab-based cooking tests; Nawraj and Karma Sherpa for logistic support; Kaitlyn Daugherty for measurement of water-soluble organic carbon; Gavin Parker for quantification of antimony; and David Peate for training and access to ICP-MS instrumentation that was purchased through the NSF Major Research Instrumentation program (grant EAR-0821615).

Edited by: James Allan

Reviewed by: three anonymous referees

\section{References}

Adhikary, B., Carmichael, G. R., Tang, Y., Leung, L. R., Qian, Y., Schauer, J. J., Stone, E. A., Ramanathan, V., and Ramana, M. V.: Characterization of the seasonal cycle of south Asian aerosols: A regional-scale modeling analysis, J. Geophys. Res.-Atmos., 112, D22S22, https://doi.org/10.1029/2006JD008143, 2007.

Akagi, S. K., Yokelson, R. J., Wiedinmyer, C., Alvarado, M. J., Reid, J. S., Karl, T., Crounse, J. D., and Wennberg, P. O.: Emission factors for open and domestic biomass burning for use in atmospheric models, Atmos. Chem. Phys., 11, 4039-4072, https://doi.org/10.5194/acp-11-4039-2011, 2011.

Al-Naiema, I., Estillore, A. D., Mudunkotuwa, I. A., Grassian, V. H., and Stone, E. A.: Impacts of Co-firing Biomass on Emissions of Particulate Matter to the Atmosphere, Fuel, 162, 111120, https://doi.org/10.1016/j.fuel.2015.08.054, 2015.

Arora, P., Jain, S., and Sachdeva, K.: Laboratory based assessment of cookstove performance using energy and emission parameters for North Indian cooking cycle, Biomass Bioenerg., 69, 211-221, https://doi.org/10.1016/j.biombioe.2014.07.012, 2014.

Aryal, R. K., Lee, B.-K., Karki, R., Gurung, A., Baral, B., and Byeon, S.-H.: Dynamics of $\mathrm{PM}_{2.5}$ concentrations in Kathmandu Valley, Nepal, J. Hazardous Mater., 168, 732-738, https://doi.org/10.1016/j.jhazmat.2009.02.086, 2009.

Bond, T. C., Streets, D. G., Yarber, K. F., Nelson, S. M., Woo, J.-H., and Klimont, Z.: A technology-based global inventory of black and organic carbon emissions from combustion, J. Geophys. Res.-Atmos., 109, D14203, https://doi.org/10.1029/2003jd003697, 2004.

Bond, T. C., Doherty, S. J., Fahey, D. W., Forster, P. M., Berntsen, T., DeAngelo, B. J., Flanner, M. G., Ghan, S., Kärcher, B., Koch, D., Kinne, S., Kondo, Y., Quinn, P. K., Sarofim, M. C., Schultz, M. G., Schulz, M., Venkataraman, C., Zhang, H., Zhang, S., Bellouin, N., Guttikunda, S. K., Hopke, P. K., Jacobson, M. Z., Kaiser, J. W., Klimont, Z., Lohmann, U., Schwarz, J. P., Shindell, D., Storelvmo, T., Warren, S. G., and Zender, C. S.: Bounding the role of black carbon in the climate system: A scientific assessment, J. Geophys. Res.-Atmos., 118, 5380-5552, https://doi.org/10.1002/jgrd.50171, 2013.

Budisulistiorini, S. H., Li, X., Bairai, S. T., Renfro, J., Liu, Y., Liu, Y. J., McKinney, K. A., Martin, S. T., McNeill, V. F., Pye, H. O. T., Nenes, A., Neff, M. E., Stone, E. A., Mueller, S., Knote, C., Shaw, S. L., Zhang, Z., Gold, A., and Surratt, J. D.: Examining the effects of anthropogenic emissions on isoprenederived secondary organic aerosol formation during the 2013 Southern Oxidant and Aerosol Study (SOAS) at the Look Rock, Tennessee ground site, Atmos. Chem. Phys., 15, 8871-8888, https://doi.org/10.5194/acp-15-8871-2015, 2015

Christian, T. J., Yokelson, R. J., Cárdenas, B., Molina, L. T., Engling, G., and Hsu, S.-C.: Trace gas and particle emissions from domestic and industrial biofuel use and garbage burning in central Mexico, Atmos. Chem. Phys., 10, 565-584, https://doi.org/10.5194/acp-10-565-2010, 2010.

Davidson, C. I., Lin, S. F., Osborn, J. F., Pandey, M. R., Rasmussen, R. A., and Khalil, M. A. K.: Indoor and outdoor air pollution in the Himalayas, Environ. Sci. Technol., 20, 561-567, https://doi.org/10.1021/es00148a003, 1986.

Deka, P. and Hoque, R. R.: Chemical characterization of biomass fuel smoke particles of rural kitchens 
of South Asia, Atmos. Environ., 108, 125-132, https://doi.org/10.1016/j.atmosenv.2015.02.076, 2015.

Downard, J., Singh, A., Bullard, R., Jayarathne, T., Rathnayake, C. M., Simmons, D. L., Wels, B. R., Spak, S. N., Peters, T., Beardsley, D., Stanier, C. O., and Stone, E. A.: Uncontrolled combustion of shredded tires in a landfill - Part 1: Characterization of gaseous and particulate emissions, Atmos. Environ., 104, 195204, https://doi.org/10.1016/j.atmosenv.2014.12.059, 2015.

EPA: AP-42: Compilation of air pollutant emission factors, Chapter 3: Stationary Internal Combustion Sources (see Table 3.3-2), Office of Air Quality Planning and Standards, Office of Air and Radiation, 5th Edn., Volume 1, Research Triangle Park, NC, https://www.epa.gov/air-emissions-factors-and-quantification/ ap-42-compilation-air-emission-factors, last access: September, 1996.

Fine, P. M., Cass, G. R., and Simoneit, B. R. T.: Chemical characterization of fine particle emissions from fireplace combustion of woods grown in the northeastern United States, Environ. Sci. Technol., 35, 2665-2675, https://doi.org/10.1021/es001466k, 2001.

FNBI: Federation of Nepal Brick Industries, http://www.fnbi.org. $\mathrm{np} /$, last access: December 2016.

Fullerton, D. G., Bruce, N., and Gordon, S. B.: Indoor air pollution from biomass fuel smoke is a major health concern in the developing world, T. Roy. Soc. Trop. Med. H., 102, 843-851, https://doi.org/10.1016/j.trstmh.2008.05.028, 2008.

Gerstle, R. W. and Kemnitz, D. A.: Atmospheric Emissions from Open Burning, JAPCA J. Air Waste Ma., 17, 324-327, https://doi.org/10.1080/00022470.1967.10468988, 1967.

Goetz, J. D., Giordano, M. R., Stockwell, C. E., Maharjan, R., Adhikari, S., Bhave, P. V., Praveen, P. S., Panday, A. K., Jayarathne, T., Stone, E. A., Yokelson, R. J., and DeCarlo, P. F.: Speciated On-line PM1 from South Asian Combustion Sources: Part I, Fuel-based Emission Factors and Size Distributions, Atmos. Chem. Phys. Discuss., in preparation, 2018a.

Goetz, J. D., Giordano, M. R., Stockwell, C. E., Maharjan, R., Adhikari, S., Bhave, P. V., Praveen, P. S., Panday, A. K., Jayarathne, T., Stone, E. A., Yokelson, R. J., and DeCarlo, P. F.: On-line PM1 from South Asian Combustion Sources: Part II, AMS Mass Spectral Profiles and Wavelength Dependence, Atmos. Chem. Phys. Discuss., in preparation, 2018b.

Gupta, S., Saksena, S., Shankar, V. R., and Joshi, V.: Emission factors and thermal efficiencies of cooking biofuels from five countries, Biomass Bioenerg., 14, 547-559, https://doi.org/10.1016/s0961-9534(98)00010-5, 1998.

Gurung, A. and Bell, M. L.: The state of scientific evidence on air pollution and human health in Nepal, Environ. Res., 124, 54-64, https://doi.org/10.1016/j.envres.2013.03.007, 2013.

Guttikunda, S. K., Begum, B. A., and Wadud, Z.: Particulate pollution from brick kiln clusters in the Greater Dhaka region, Bangladesh, Air Qual. Atmos. Health, 6, 357-365, https://doi.org/10.1007/s11869-012-0187-2, 2013.

IARC: Diesel and gasoline engine exhausts and some nitroarenes, International Agency for Research on Cancer, Lyon, France, WHOISBM 97892832 01434; ISSN 1017-1606, 2013.

Jacobson, M. Z.: Fundamentals of Atmospheric Modeling, 2nd Edn., Cambridge University Press, 2005.

Jayarathne, T., Stockwell, C. E., Yokelson, R. J., Nakao, S., and Stone, E. A.: Emissions of Fine Particle Fluoride from
Biomass Burning, Environ. Sci. Technol., 48, 12636-12644, https://doi.org/10.1021/es502933j, 2014.

Jetter, J., Zhao, Y. X., Smith, K. R., Khan, B., Yelverton, T., DeCarlo, P., and Hays, M. D.: Pollutant Emissions and Energy Efficiency under Controlled Conditions for Household Biomass Cookstoves and Implications for Metrics Useful in Setting International Test Standards, Environ. Sci. Technol., 46, 1082710834, https://doi.org/10.1021/es301693f, 2012.

Jetter, J. J. and Kariher, P.: Solid-fuel household cook stoves: Characterization of performance and emissions, Biomass Bioenerg., 33, 294-305, https://doi.org/10.1016/j.biombioe.2008.05.014, 2009.

Johnson, M., Edwards, R., Frenk, C. A., and Masera, O.: In-field greenhouse gas emissions from cookstoves in rural Mexican households, Atmos. Environ., 42, 1206-1222, https://doi.org/10.1016/j.atmosenv.2007.10.034, 2008.

Kar, A., Rehman, I. H., Burney, J., Puppala, S. P., Suresh, R., Singh, L., Singh, V. K., Ahmed, T., Ramanathan, N., and Ramanathan, V.: Real-Time Assessment of Black Carbon Pollution in Indian Households Due to Traditional and Improved Biomass Cookstoves, Environ. Sci. Technol., 46, 2993-3000, https://doi.org/10.1021/es203388g, 2012.

Kaushik, R., Khaliq, F., Subramaneyaan, M., and Ahmed, R. S.: Pulmonary dysfunctions, oxidative stress and DNA damage in brick kiln workers, Hum. Exp. Toxicol., 31, 1083-1091, https://doi.org/10.1177/0960327112450899, 2012.

Keene, W. C., Lobert, R. M., Crutzen, P. J., Maben, J. R., Scharffe, D. H., Landmann, T., Hely, C., and Brain, C.: Emissions of major gaseous and particulate species during experimental burns of southern African biomass, J. Geophys. Res.-Atmos., 111, D04301, https://doi.org/10.1029/2005jd006319, 2006.

Kirchstetter, T. W., Corrigan, C. E., and Novakov, T.: Laboratory and field investigation of the adsorption of gaseous organic compounds onto quartz filters, Atmos. Environ., 35, 1663-1671, https://doi.org/10.1016/s1352-2310(00)00448-9, 2001.

Kshirsagar, M. P. and Kalamkar, V. R.: A comprehensive review on biomass cookstoves and a systematic approach for modern cookstove design, Renew. Sust. Energ. Rev., 30, 580-603, https://doi.org/10.1016/j.rser.2013.10.039, 2014.

Lee, H., Wang, L., and Shih, J. F.: Mutagenicity of particulates from the laboratory combustion of plastics, Mutat. Res. Lett., 346, 135-144, https://doi.org/10.1016/0165-7992(95)90045-4, 1995.

Lemieux, P. M., Lutes, C. C., Abbott, J. A., and Aldous, K. M.: Emissions of Polychlorinated Dibenzo-p-dioxins and Polychlorinated Dibenzofurans from the Open Burning of Household Waste in Barrels, Environ. Sci. Technol., 34, 377-384, https://doi.org/10.1021/es990465t, 2000.

Liang, F. Y., Lu, M. M., Keener, T. C., Liu, Z. F., and Khang, S. J.: The organic composition of diesel particulate matter, diesel fuel and engine oil of a non-road diesel generator, J. Environ. Monit., 7, 983-988, https://doi.org/10.1039/b504728e, 2005.

Lin, Y. C., Lee, W. J., and Hou, H. C.: PAH emissions and energy efficiency of palm-biodiesel blends fueled on diesel generator, Atmos. Environ., 40, 3930-3940, https://doi.org/10.1016/j.atmosenv.2006.02.026, 2006.

Lipsky, E. M. and Robinson, A. L.: Effects of dilution on fine particle mass and partitioning of semivolatile organics in diesel exhaust and wood smoke, Environ. Sci. Technol., 40, 155-162, https://doi.org/10.1021/es050319p, 2006. 
Liu, Z. F., Lu, M. M., Birch, M. E., Keener, T. C., Khang, S. J., and Liang, F. Y.: Variations of the particulate carbon distribution from a nonroad diesel generator, Environ. Sci. Technol., 39, 7840-7844, https://doi.org/10.1021/es048373d, 2005.

Lough, G. C., Christenson, C. C., Schauer, J. J., Tortorelli, J., Bean, E., Lawson, D., Clark, N. N., and Gabele, P. A.: Development of Molecular Marker Source Profiles for Emissions from On-Road Gasoline and Diesel Vehicle Fleets, JAPCA J. Air Waste Ma., 57, 1190-1199, https://doi.org/10.3155/1047-3289.57.10.1190, 2007.

Maithel, S., Lalchandani, D., Malhotra, G., Bhanware, P., Uma, R., Ragavan, S., Athalye, V., Bindiya, K. R., Reddy, S., Bond, T., Weyant, C., Baum, E., Thoa, V. T. K., Phuong, N. T., and Thanh, T. K.: Brick Kilns Performance Assessment: A Roadmap for Cleaner Brick Production in India, Greentech, New Dehli, available at: http://www.catf.us/resources/publications/files/Brick_ Kilns_Performance_Assessment.pdf (last access: November 2017), 2012.

Martin, S. T.: Phase Transitions of Aqueous Atmospheric Particles, Chem. Rev., 100, 3403-3454, https://doi.org/10.1021/cr990034t, 2000.

McMeeking, G. R., Kreidenweis, S. M., Baker, S., Carrico, C. M., Chow, J. C., Collett, J. L., Hao, W. M., Holden, A. S., Kirchstetter, T. W., Malm, W. C., Moosmuller, H., Sullivan, A. P., and Wold, C. E.: Emissions of trace gases and aerosols during the open combustion of biomass in the laboratory, J. Geophys. Res.Atmos., 114, D19210, https://doi.org/10.1029/2009jd011836, 2009.

MoPIT: Ministry of Physical Infrastructure \& Transport, http:// www.mopit.gov.np/ (last access: December 2016), 2014.

Mukherji, A.: Spatio-temporal analysis of markets for groundwater irrigation services in India: 1976-1977 to 1997-1998, Hydrogeol. J., 16, 1077-1087, https://doi.org/10.1007/s10040-0080287-0, 2008.

NIOSH: Diesel Particulate Matter (as Elemental Carbon), NIOSH Manual of Analytical Methods, Method 5040, available at: https: //www.cdc.gov/niosh/docs/2003-154/pdfs/5040.pdf (last access: November 2017), 2003.

Nolte, C. G., Schauer, J. J., Cass, G. R., and Simoneit, B. R.: Trimethylsilyl derivatives of organic compounds in source samples and in atmospheric fine particulate matter, Environ. Sci. Technol., 36, 4273-4281, https://doi.org/10.1021/es020518y, 2002.

Oanh, N. T. K., Reutergardh, L. B., and Dung, N. T.: Emission of polycyclic aromatic hydrocarbons and particulate matter from domestic combustion of selected fuels, Environ. Sci. Technol., 33, 2703-2709, https://doi.org/10.1021/es980853f, 1999.

Oanh, N. T. K., Mai, T. T. P., and Permadi, D. A.: Analysis of motorcycle fleet in Hanoi for estimation of air pollution emission and climate mitigation co-benefit of technology implementation, Atmos. Environ., 59, 438-448, https://doi.org/10.1016/j.atmosenv.2012.04.057, 2012.

Oros, D. R. and Simoneit, B. R. T.: Identification and emission rates of molecular tracers in coal smoke particulate matter, Fuel, 79, 515-536, https://doi.org/10.1016/S0016-2361(99)00153-2, 2000.

Panday, A. K., Prinn, R. G., and Schar, C.: Diurnal cycle of air pollution in the Kathmandu Valley, Nepal: 2.
Modeling results, J. Geophys. Res.-Atmos., 114, D21308, https://doi.org/10.1029/2008jd009808, 2009.

Pope, D. P., Mishra, V., Thompson, L., Siddiqui, A. R., Rehfuess, E. A., Weber, M., and Bruce, N. G.: Risk of Low Birth Weight and Stillbirth Associated With Indoor Air Pollution From Solid Fuel Use in Developing Countries, Epidemiol. Rev., 32, 70-81, https://doi.org/10.1093/epirev/mxq005, 2010.

Rajput, P., Sarin, M., Sharma, D., and Singh, D.: Characteristics and emission budget of carbonaceous species from post-harvest agricultural-waste burning in source region of the Indo-Gangetic Plain, Tellus B, 66, 21026 , https://doi.org/10.3402/tellusb.v66.21026, 2014a.

Rajput, P., Sarin, M. M., Sharma, D., and Singh, D.: Organic aerosols and inorganic species from post-harvest agriculturalwaste burning emissions over northern India: impact on mass absorption efficiency of elemental carbon, Environ. Sci.-Proc. Imp., 16, 2371-2379, https://doi.org/10.1039/c4em00307a, 2014b.

Ramanathan, V., Chung, C., Kim, D., Bettge, T., Buja, L., Kiehl, J. T., Washington, W. M., Fu, Q., Sikka, D. R., and Wild, M.: Atmospheric brown clouds: Impacts on South Asian climate and hydrological cycle, P. Natl. Acad. Sci. USA, 102, 5326-5333, https://doi.org/10.1073/pnas.0500656102, 2005.

Ramanathan, V. and Carmichael, G.: Global and regional climate changes due to black carbon, Nat. Geosci., 1, 221-227, https://doi.org/10.1038/ngeo156, 2008.

Ravindra, K., Sokhi, R., and Van Grieken, R.: Atmospheric polycyclic aromatic hydrocarbons: Source attribution, emission factors and regulation, Atmos. Environ., 42, 2895-2921, https://doi.org/10.1016/j.atmosenv.2007.12.010, 2008.

Rawat, S. and Mukherji, A.: Poor state of irrigation statistics in India: the case of pumps, wells and tubewells, Int. J. Water Resour. D, 30, 262-281, https://doi.org/10.1080/07900627.2013.837361, 2014.

Roden, C. A., Bond, T. C., Conway, S., Pinel, A. B. S., MacCarty, N., and Still, D.: Laboratory and field investigations of particulate and carbon monoxide emissions from traditional and improved cookstoves, Atmos. Environ., 43, 1170-1181, https://doi.org/10.1016/j.atmosenv.2008.05.041, 2009.

Sarkar, C., Sinha, V., Kumar, V., Rupakheti, M., Panday, A., Mahata, K. S., Rupakheti, D., Kathayat, B., and Lawrence, M. G.: Overview of VOC emissions and chemistry from PTR-TOFMS measurements during the SusKat-ABC campaign: high acetaldehyde, isoprene and isocyanic acid in wintertime air of the Kathmandu Valley, Atmos. Chem. Phys., 16, 3979-4003, https://doi.org/10.5194/acp-16-3979-2016, 2016.

Saud, T., Singh, D. P., Mandal, T. K., Gadi, R., Pathak, H., Saxena, M., Sharma, S. K., Gautam, R., Mukherjee, A., and Bhatnagar, R. P.: Spatial distribution of biomass consumption as energy in rural areas of the Indo-Gangetic plain, Biomass Bioenerg., 35, 932-941, https://doi.org/10.1016/j.biombioe.2010.11.001, 2011.

Saud, T., Saxena, M., Singh, D. P., Saraswati, Dahiya, M., Sharma, S. K., Datta, A., Gadi, R., and Mandal, T. K.: Spatial variation of chemical constituents from the burning of commonly used biomass fuels in rural areas of the IndoGangetic Plain (IGP), India, Atmos. Environ., 71, 158-169, https://doi.org/10.1016/j.atmosenv.2013.01.053, 2013.

Schauer, J. J., Rogge, W. F., Hildemann, L. M., Mazurek, M. A., and Cass, G. R.: Source apportionment of airborne particulate matter 
using organic compounds as tracers, Atmos. Environ., 30, 38373855, https://doi.org/10.1016/1352-2310(96)00085-4, 1996.

Schauer, J. J., Kleeman, M. J., Cass, G. R., and Simoneit, B. R. T.: Measurement of emissions from air pollution sources, 2. C-1 through C-30 organic compounds from medium duty diesel trucks, Environ. Sci. Technol., 33, 1578-1587, https://doi.org/10.1021/es980081n 10.1021/es980081n, 1999.

Schauer, J. J., Kleeman, M. J., Cass, G. R., and Simoneit, B. R. T.: Measurement of emissions from air pollution sources. 5. C-1-C-32 organic compounds from gasolinepowered motor vehicles, Environ. Sci. Technol., 36, 1169-1180, https://doi.org/10.1021/es0108077, 2002.

Shah, S. D., Cocker, D. R., Johnson, K. C., Lee, J. M., Soriano, B. L., and Miller, J. W.: Emissions of regulated pollutants from inuse diesel back-up generators, Atmos. Environ., 40, 4199-4209, https://doi.org/10.1016/j.atmosenv.2005.12.063, 2006a.

Shah, T., Singh, O. P., and Mukherji, A.: Some aspects of South Asia's groundwater irrigation economy: analyses from a survey in India, Pakistan, Nepal Terai and Bangladesh, Hydrogeol. J., 14, 286-309, https://doi.org/10.1007/s10040-005-0004$1,2006 \mathrm{~b}$.

Shah, T.: Climate change and groundwater: India's opportunities for mitigation and adaptation, Environ. Res. Lett., 4, 035005, https://doi.org/10.1088/1748-9326/4/3/035005, 2009.

Sheesley, R. J., Schauer, J. J., Chowdhury, Z., Cass, G. R., and Simoneit, B. R. T.: Characterization of organic aerosols emitted from the combustion of biomass indigenous to South Asia, J. Geophys. Res.-Atmos., 108, 4285, https://doi.org/10.1029/2002JD002981, 2003.

Shrestha, S. R., Nguyen Thi Kim, O., Xu, Q., Rupakheti, M., and Lawrence, M. G.: Analysis of the vehicle fleet in the Kathmandu Valley for estimation of environment and climate cobenefits of technology intrusions, Atmos. Environ., 81, 579-590, https://doi.org/10.1016/j.atmosenv.2013.09.050, 2013.

Simoneit, B. R., Schauer, J. J., Nolte, C., Oros, D. R., Elias, V. O., Fraser, M., Rogge, W., and Cass, G. R.: Levoglucosan, a tracer for cellulose in biomass burning and atmospheric particles, Atmos. Environ., 33, 173-182, https://doi.org/10.1016/S13522310(98)00145-9, 1999.

Simoneit, B. R. T., Medeiros, P. M., and Didyk, B. M.: Combustion products of plastics as indicators for refuse burning in the atmosphere, Environ. Sci. Technol., 39, 6961-6970, https://doi.org/10.1021/es050767x, 2005.

Singh, A., Rajput, P., Sharma, D., Sarin, M. M., and Singh, D.: Black Carbon and Elemental Carbon from Postharvest Agricultural-Waste Burning Emissions in the Indo-Gangetic Plain, Adv. Meteorol., 2014, 179301, https://doi.org/10.1155/2014/179301, 2014.

Smith, K. R., Uma, R., Kishore, V. V. N., Zhang, J. F., Joshi, V., and Khalil, M. A. K.: Greenhouse implications of household stoves: An analysis for India, Annu. Rev. Energ. Env., 25, 741763, https://doi.org/10.1146/annurev.energy.25.1.741, 2000.

Smith, K. R., Frumkin, H., Balakrishnan, K., Butler, C. D., Chafe, Z. A., Fairlie, I., Kinney, P., Kjellstrom, T., Mauzerall, D. L., McKone, T. E., McMichael, A. J., and Schneider, M.: Energy and Human Health, Annu. Rev. Publ. Health, 34, 159-188, https://doi.org/10.1146/annurevpublhealth-031912-114404, 2013.
Spezzano, P., Picini, P., Cataldi, D., Messale, F., and Manni, C.: Particle- and gas-phase emissions of polycyclic aromatic hydrocarbons from two-stroke, 50-cm(3) mopeds, Atmos. Environ., 42, 4332-4344, https://doi.org/10.1016/j.atmosenv.2008.01.008, 2008.

Stockwell, C. E., Yokelson, R. J., Kreidenweis, S. M., Robinson, A. L., DeMott, P. J., Sullivan, R. C., Reardon, J., Ryan, K. C., Griffith, D. W. T., and Stevens, L.: Trace gas emissions from combustion of peat, crop residue, domestic biofuels, grasses, and other fuels: configuration and Fourier transform infrared (FTIR) component of the fourth Fire Lab at Missoula Experiment (FLAME-4), Atmos. Chem. Phys., 14, 9727-9754, https://doi.org/10.5194/acp-14-9727-2014, 2014.

Stockwell, C. E., Christian, T. J., Goetz, J. D., Jayarathne, T., Bhave, P. V., Praveen, P. S., Adhikari, S., Maharjan, R., DeCarlo, P. F., Stone, E. A., Saikawa, E., Blake, D. R., Simpson, I. J., Yokelson, R. J., and Panday, A. K.: Nepal Ambient Monitoring and Source Testing Experiment (NAMaSTE): emissions of trace gases and light-absorbing carbon from wood and dung cooking fires, garbage and crop residue burning, brick kilns, and other sources, Atmos. Chem. Phys., 16, 11043-11081, https://doi.org/10.5194/acp-16-11043-2016, 2016.

Stone, E. A., Schauer, J. J., Pradhan, B. B., Dangol, P. M., Habib, G., Venkataraman, C., and Ramanathan, V.: Characterization of emissions from South Asian biofuels and application to source apportionment of carbonaceous aerosol in the Himalayas, J. Geophys. Res.-Atmos., 115, D06301, https://doi.org/10.1029/2009jd011881, 2010.

Stone, E. A., Nguyen, T. T., Pradhan, B. B., and Dangol, P. M.: Assessment of Biogenic Secondary Organic Aerosol in the Himalayas, Environ. Chem., 9, 263-272, https://doi.org/10.1071/EN12002, 2012.

Tsyro, S. G.: To what extent can aerosol water explain the discrepancy between model calculated and gravimetric $\mathrm{PM}_{10}$ and $\mathrm{PM}_{2.5}$ ?, Atmos. Chem. Phys., 5, 515-532, https://doi.org/10.5194/acp-5-515-2005, 2005.

UNEP: Factsheets about brick kilns in South and South-East Asia: Natural draught zigzag firing technology, United Nations Environment Programme, available at: http://www.ccacoalition.org/ en/file/857/download?token $=$ mDBTUhWb (last access: November 2017), 2014.

USEPA: Method 3052: Microwave Assisted Acid Digestion of Siliceous and Organically Based Matrices, Test Methods for Evaluating Solid Waste, United States Environmental Protection Agency, 1995.

Venkataraman, C. and Rao, G. U. M.: Emission factors of carbon monoxide and size-resolved aerosols from biofuel combustion, Environ. Sci. Technol., 35, 2100-2107, https://doi.org/10.1021/es001603d, 2001.

Venkataraman, C., Habib, G., Eiguren-Fernandez, A., Miguel, A. H., and Friedlander, S. K.: Residential biofuels in south Asia: Carbonaceous aerosol emissions and climate impacts, Science, 307, 1454-1456, https://doi.org/10.1126/science.1104359, 2005.

Ward, D. E. and Radke, L. F.: Emissions measurements from vegetation fires: A comparative evaluation of methods and results, Fire in the Environment: The Ecological, Atmospheric and Climatic Importance of Vegetation Fires, edited by: Crutzen, P. J. and Goldammer, J. G., John Wiley, New York, 1993. 
WECS: Energy Consumption Situation in Nepal (Year 2011/12), Water and Energy Commission Secretariat, Kathmandu, Nepal, available at: http://energyefficiency.gov.np/downloadthis/final_ data_book_11_june_2014.pdf (last access:), 2014.

Weyant, C., Athalye, V., Ragavan, S., Rajarathnam, U., Lalchandani, D., Maithel, S., Baum, E., and Bond, T. C.: Emissions from South Asian Brick Production, Environ. Sci. Technol., 48, 64776483, https://doi.org/10.1021/es500186g, 2014.

Wiedinmyer, C., Yokelson, R. J., and Gullett, B. K.: Global Emissions of Trace Gases, Particulate Matter, and Hazardous Air Pollutants from Open Burning of Domestic Waste, Environ. Sci. Technol., 48, 9523-9530, https://doi.org/10.1021/es502250z, 2014.

Woodall, B. D., Yamamoto, D. P., Gullett, B. K., and Touati, A.: Emissions from Small-Scale Burns of Simulated Deployed U.S. Military Waste, Environ. Sci. Technol., 46, 10997-11003, https://doi.org/10.1021/es3021556, 2012.

Yevich, R. and Logan, J. A.: An assessment of biofuel use and burning of agricultural waste in the developing world, Global Biogeochem. Cy., 17, 1095, https://doi.org/10.1029/2002gb001952, 2003.

Yokelson, R. J., Griffith, D. W. T., and Ward, D. E.: Openpath Fourier transform infrared studies of large-scale laboratory biomass fires, J. Geophys. Res.-Atmos., 101, 21067-21080, https://doi.org/10.1029/96JD01800, 1996.

Yokelson, R. J., Goode, J. G., Ward, D. E., Susott, R. A., Babbitt, R. E., Wade, D. D., Bertschi, I., Griffith, D. W. T., and Hao, W. M.: Emissions of formaldehyde, acetic acid, methanol, and other trace gases from biomass fires in North Carolina measured by airborne Fourier transform infrared spectroscopy, J. Geophys. Res.-Atmos., 104, 30109-30125, https://doi.org/10.1029/1999jd900817, 1999.
Zhang, Y., Stedman, D. H., Bishop, G. A., Guenther, P. L., and Beaton, S. P.: Worldwide On-Road Vehicle Exhaust Emissions Study by Remote Sensing, Environ. Sci. Technol., 29, 22862294, https://doi.org/10.1021/es00009a020, 1995.

Zhang, Y. X., Schauer, J. J., Zhang, Y. H., Zeng, L. M., Wei, Y. J., Liu, Y., and Shao, M.: Characteristics of particulate carbon emissions from real-world Chinese coal combustion, Environ. Sci. Technol., 42, 5068-5073, https://doi.org/10.1021/es7022576, 2008.

Zhu, D. Z., Nussbaum, N. J., Kuhns, H. D., Chang, M. C. O., Sodeman, D., Uppapalli, S., Moosmuller, H., Chow, J. C., and Watson, J. G.: In-Plume Emission Test Stand 2: Emission Factors for 10to $100-\mathrm{kW}$ US Military Generators, JAPCA J. Air Waste Ma., 59, 1446-1457, https://doi.org/10.3155/1047-3289.59.12.1446, 2009.

Zielinska, B., Campbell, D., Lawson, D. R., Ireson, R. G., Weaver, C. S., Hesterberg, T. W., Larson, T., Davey, M., and Liu, L. J. S.: Detailed characterization and profiles of crankcase and diesel particulate matter exhaust emissions using speciated organics, Environ. Sci. Technol., 42, 5661-5666, https://doi.org/10.1021/es703065h, 2008.

Zuskin, E., Mustajbegovic, J., Schachter, E. N., Kern, J., DokoJelinic, J., and Godnic-Cvar, J.: Respiratory findings in workers employed in the brick-manufacturing industry, J. Occup. Environ. Med., 40, 814-820, https://doi.org/10.1097/00043764199809000-00011, 1998. 